\title{
Promotion effect of rare-earth elements on the catalytic decomposition of ammonia over $\mathrm{Ni} / \mathrm{Al}_{2} \mathrm{O}_{3}$ catalyst
}

Kaname Okura, Takeou Okanishi, Hiroki Muroyama, Toshiaki Matsui, and Koichi

Eguchi*

Department of Energy and Hydrocarbon Chemistry, Graduate School of Engineering,

Kyoto University, Nishikyo-ku, Kyoto 615-8510, Japan

* Correspondence should be addressed to

Koichi Eguchi

Department of Energy and Hydrocarbon Chemistry,

Graduate School of Engineering, Kyoto University,

Nishikyo-ku, Kyoto 615-8510, JAPAN

TEL: +81-75-383-2519, FAX: +81-75-383-2520

E-mail: eguchi@scl.kyoto-u.ac.jp 


\begin{abstract}
Ammonia decomposition has attracted much attention as an efficient method for the on-site generation of hydrogen. In this study, alumina-supported nickel catalysts $\left(\mathrm{Ni} / \mathrm{Al}_{2} \mathrm{O}_{3}\right)$ modified by rare-earth elements were prepared by the impregnation method and their catalytic activity for the ammonia decomposition was investigated. The addition of rare-earth elements promoted the decomposition reaction over catalysts and the La-modified catalyst achieved the highest ammonia conversion in this work. For the modified catalysts, the adsorbed hydrogen, which is known to be an inhibitive species for the ammonia decomposition, desorbed at lower temperature compared to the unmodified one. Therefore, the effective alleviation of hydrogen inhibition would be responsible for the activity enhancement for the modified catalysts. The reaction kinetics study also supported this proposed mechanism. For the La-modified catalyst, the optimal pretreatment condition was investigated to enhance the catalytic activity. The catalyst calcined at $400^{\circ} \mathrm{C}$ followed by reduction at $600^{\circ} \mathrm{C}$ exhibited the highest ammonia conversion of $94 \%$ at $550^{\circ} \mathrm{C}$.
\end{abstract}

Keywords: Ammonia decomposition; Nickel catalyst; Rare-earth elements; Additive effect 


\section{Introduction}

In recent years, fuel cells have attracted much attention as promising power generation devices because of high energy conversion efficiency and low emission. Hydrogen is a primary fuel source for fuel cells especially operated at low temperatures. However, the storage and transportation of hydrogen are major obstacles for the spread of fuel cell systems due to its low volumetric density and boiling point. For this reason, on-site generation of hydrogen has been accomplished by the reforming of hydrocarbons. However, CO is produced as a by-product upon the reforming process and degrades the performance of Pt electrode in polymer electrolyte fuel cells (PEFCs). Thus, the CO concentration in the fuel gas is reduced less than $10 \mathrm{ppm}$ via water gas shift reaction and preferential oxidation reaction in the residential PEFC cogeneration system [1, 2]. This makes the system complicated.

Ammonia is regarded as a prospective hydrogen carrier because of its favorable properties for on-site hydrogen generation. Ammonia can be liquefied under mild conditions $\left(-33.4^{\circ} \mathrm{C}\right.$ at atmospheric pressure or 8.46 atm at $\left.20^{\circ} \mathrm{C}\right)$ and possesses high hydrogen storage capacity (17.6wt.\%) compared to other hydrogen carriers. In addition, the hydrogen production via the ammonia decomposition does not emit CO. This decomposition process corresponds to a reverse reaction of ammonia synthesis. Ammonia decomposes endothermically into nitrogen and hydrogen as follows;

$$
2 \mathrm{NH}_{3} \rightarrow \mathrm{N}_{2}+3 \mathrm{H}_{2} \quad \Delta H^{\mathrm{o}}=+46 \mathrm{~kJ} \mathrm{~mol}^{-1}
$$

Many studies have been reported for the development of ammonia decomposition catalysts such as metals, alloys, carbides, and nitrides, and it was revealed that $\mathrm{Ru}, \mathrm{Ir}, \mathrm{Ni}$, Rh, Pt, Pd, and Fe metals, $\mathrm{MoN}_{x}$, and $\mathrm{VC}_{x}$ catalysts promoted this reaction [2-22]. Since $\mathrm{Ru}$ catalysts are the most active among them, much effort has been devoted for the catalyst development [8-17]. In previous reports, $\mathrm{Ru}$ catalysts supported on carbon nanotube (CNT) showed very high activity for ammonia decomposition because the high surface area of CNT enabled high dispersion of Ru species [2, 8, 9]. Moreover, the addition of basic components such as alkali metals to the catalysts promoted the 
decomposition reaction. These species could facilitate the combinative desorption of nitrogen atoms, which is generally accepted as the rate-determining step in the ammonia decomposition, via the electron transfer from the additives to active species. Especially, the prominent effect of basic additives was confirmed for the CNT-supported catalysts due to high electron conductivity of CNT as compared with other metal oxide supports [8]. Recently, it was reported that the Ru catalyst supported on inorganic electride, $\left[\mathrm{Ca}_{24} \mathrm{Al}_{28} \mathrm{O}_{64}\right]^{4+}\left(\mathrm{e}^{-}\right)^{4}$, showed higher activity than K-modified $\mathrm{Ru} /$ graphite carbon and Cs-modified $\mathrm{Ru} / \mathrm{MgO}$ catalysts. The electron injection from the electride to the antibonding orbital of $\mathrm{Ru}-\mathrm{N}$ bond reduced the activation energy of decomposition reaction [14]. However, the limited availability of noble metals makes it necessary to develop catalysts with low cost. Thus, Ni catalysts have attracted much interest as alternative materials for ammonia decomposition because they attained the highest activity among non-noble metal catalysts [15-22]. In previous works, La and Ce species were known as effective promoters for Ni catalysts [20-22]. However, the promotion effect of other rare-earth elements has not been investigated sufficiently for Ni catalysts. In this study, therefore, we investigated the activity of $\mathrm{Ni} / \mathrm{Al}_{2} \mathrm{O}_{3}$ catalysts modified by various rare-earth elements for ammonia decomposition. To clarify the additive effects on the reaction behavior of reactant and products during ammonia decomposition, their desorption processes were also examined. Besides, the kinetics analysis was carried out to elucidate the influence of hydrogen, which is known to be an inhibitive species for the ammonia decomposition [2, 14, 26, 27], on the catalytic performance. Furthermore, the optimization of heat treatment condition for the synthesis of La-modified catalyst was conducted because the La element significantly enhanced the catalytic activity of $\mathrm{Ni} / \mathrm{Al}_{2} \mathrm{O}_{3}$. 


\section{Experimental}

\subsection{Sample preparation}

$\mathrm{Ni} / \mathrm{Al}_{2} \mathrm{O}_{3}$ catalysts modified by rare-earth elements were prepared by the impregnation method. $\mathrm{Ni}\left(\mathrm{NO}_{3}\right)_{2} \cdot 6 \mathrm{H}_{2} \mathrm{O}$ (Wako Pure Chemical Industries, Ltd.) and $\mathrm{Al}_{2} \mathrm{O}_{3}$ (JRC-ALO8, The Catalytic Society of Japan) were used as a nickel source and a support material, respectively. The following nitrates were applied as additive sources: $\mathrm{Y}\left(\mathrm{NO}_{3}\right)_{3} \cdot 6 \mathrm{H}_{2} \mathrm{O}$ (Sigma-Aldrich, Co.), $\mathrm{La}\left(\mathrm{NO}_{3}\right)_{3} \cdot 6 \mathrm{H}_{2} \mathrm{O}$ (Wako Pure Chemical Industries, Ltd.), $\mathrm{Ce}\left(\mathrm{NO}_{3}\right)_{3} \cdot 6 \mathrm{H}_{2} \mathrm{O}$ (Wako Pure Chemical Industries, Ltd.), $\operatorname{Pr}\left(\mathrm{NO}_{3}\right)_{3} \cdot 6 \mathrm{H}_{2} \mathrm{O}$ (Sigma-Aldrich, Co.), $\mathrm{Nd}\left(\mathrm{NO}_{3}\right)_{3} \cdot 6 \mathrm{H}_{2} \mathrm{O}$ (Wako Pure Chemical Industries, Ltd.), $\mathrm{Sm}\left(\mathrm{NO}_{3}\right)_{3} \cdot 6 \mathrm{H}_{2} \mathrm{O}$ (Wako Pure Chemical Industries, Ltd.), $\mathrm{Eu}\left(\mathrm{NO}_{3}\right)_{3} \cdot 5 \mathrm{H}_{2} \mathrm{O}$ (Sigma-Aldrich, Co.), and $\mathrm{Gd}\left(\mathrm{NO}_{3}\right)_{3} \cdot 6 \mathrm{H}_{2} \mathrm{O}$ (Wako Pure Chemical Industries, Ltd.). The $\mathrm{Al}_{2} \mathrm{O}_{3}$ support was added into an aqueous solution containing nitrates of nickel and additive elements. The mixture was kept on a steam bath at $80^{\circ} \mathrm{C}$ until the solution was evaporated. The obtained powder was calcined at $400^{\circ} \mathrm{C}-800^{\circ} \mathrm{C}$ for $5 \mathrm{~h}$ in air. The loading amounts of $\mathrm{Ni}$ metal were $10 \mathrm{wt} . \%$ and $9 \mathrm{wt} . \%$ for unmodified and modified catalysts, respectively. The amount of additive rare-earth oxides was fixed at $12 \mathrm{wt} . \%$. The atomic ratio of rare-earth elements to nickel was around 0.5.

\subsection{Characterization}

The crystal structure of the samples was analyzed by X-ray diffraction (XRD, Rigaku, Ultima IV X-ray diffractometer). The typical working condition was $40 \mathrm{kV}$ and $40 \mathrm{~mA}$ with a scanning rate of $2^{\circ} \mathrm{min}^{-1}$. The specific surface area of materials was measured by the BET method with $\mathrm{N}_{2}$ adsorption (BEL Japan, Bellsorp-miniII). Prior to the measurement, the samples were heated at $300^{\circ} \mathrm{C}$ for $30 \mathrm{~min}$ in vacuum. The surface area of metallic nickel was evaluated by the CO pulse method (BEL Japan, BELCAT-B) at $50^{\circ} \mathrm{C}$ after reduction for $2 \mathrm{~h}$. The temperature-programmed reduction (TPR) measurement was conducted to investigate the reduction behavior of the fresh catalysts (BEL Japan, BELCAT-B). Prior to the measurement, the samples were heated at $500^{\circ} \mathrm{C}$ in $\mathrm{Ar}$ to remove impurities. After cooled to $50^{\circ} \mathrm{C}$ under $\mathrm{Ar}$ flow, the samples were reduced in $4 \% \mathrm{H}_{2} / \mathrm{Ar}$ (flow rate: $30 \mathrm{ml} \mathrm{min}^{-1}$ ) in a heating process at a rate of $10^{\circ} \mathrm{C}$ 
$\min ^{-1}$. The consumption of hydrogen was monitored with a thermal conductive detector (TCD).

The ammonia temperature-programmed surface reaction $\left(\mathrm{NH}_{3}-\mathrm{TPSR}\right)$ measurement was carried out to examine the desorption behavior of the reactant and product species (BEL Japan, BELCAT-A). The samples were reduced at $600^{\circ} \mathrm{C}$ for $2 \mathrm{~h}$ in $\mathrm{H}_{2}$ and then $\mathrm{Ar}$ gas was flushed for $30 \mathrm{~min}$. $\mathrm{NH}_{3}$ adsorption was conducted at $50^{\circ} \mathrm{C}$ in pure $\mathrm{NH}_{3}$ flow for $1 \mathrm{~h}$, followed by the gas replacement by Ar for $1 \mathrm{~h}$. Subsequently, the samples were heated at a rate of $10^{\circ} \mathrm{C} \min ^{-1}$ with a supply of He (flow rate: $30 \mathrm{ml} \mathrm{min}^{-1}$ ). The desorption behavior of $\mathrm{NH}_{3}, \mathrm{H}_{2}$, and $\mathrm{N}_{2}$ were monitored by an on-line mass spectrometer (Pfeiffer Vacuum, OmniStar GSD320).

\subsection{Catalytic activity}

The resulting catalyst powder was pelletized and pulverized to 10-18 mesh. Prior to the catalytic activity test, the catalysts were reduced at $600^{\circ} \mathrm{C}$ for $2 \mathrm{~h}$ in $50 \% \mathrm{H}_{2} / \mathrm{He}$ unless otherwise noted. For the La-modified catalyst, the reduction temperature was changed in the range of $400^{\circ} \mathrm{C}-800^{\circ} \mathrm{C}$. The catalytic activity and stability were examined with a supply of pure ammonia under atmospheric pressure by using a fixed-bed reactor. The temperature dependence of ammonia conversion was studied at a space velocity of $6,000 \mathrm{l} \mathrm{kg}^{-1} \mathrm{~h}^{-1}$ in a heating process. The stability test was carried out at $600^{\circ} \mathrm{C}-700^{\circ} \mathrm{C}$ and a space velocity of $10,000 \mathrm{l} \mathrm{kg}^{-1} \mathrm{~h}^{-1}$. The flow rate of outlet gas was measured after removing unreacted ammonia by water and diluted sulfuric acid. The conversion of ammonia was evaluated by the following equation with an assumption that the produced gas was composed of nitrogen and hydrogen.

$$
\mathrm{NH}_{3} \text { conversion } / \%=\frac{F_{\text {out }}}{2 F_{\text {in }}} \times 100
$$

where $F_{\text {in }}$ and $F_{\text {out }}$ are the flow rates of inlet and outlet gases, respectively.

The kinetics analysis was performed for unmodified and modified catalysts at $450^{\circ} \mathrm{C}$ and a space velocity of $10,000 \mathrm{l} \mathrm{kg}^{-1} \mathrm{~h}^{-1}$ by varying the concentration of ammonia, 
hydrogen, or nitrogen $\left(\mathrm{NH}_{3}: 10-30 \mathrm{vol} . \%, \mathrm{H}_{2}: 10-30 \mathrm{vol} . \%, \mathrm{~N}_{2}: 10-30 \mathrm{vol} . \%\right.$, and $\mathrm{Ar}$ balance). 


\section{Results and discussion}

\subsection{Textural properties of modified $\mathrm{Ni} / \mathrm{Al}_{2} \mathrm{O}_{3}$ catalysts}

The crystal structure of the catalysts after calcination at $500^{\circ} \mathrm{C}$ was examined by XRD analysis, and the results are shown in Fig. 1. The diffraction patterns mainly consisted of the peaks attributable to $\mathrm{NiO}$ and $\mathrm{Al}_{2} \mathrm{O}_{3}$ phases for the as-calcined catalysts other than the Ce-modified one. No characteristic diffraction lines of rare-earth elements were observed in their patterns, implying that rare-earth compounds were in the amorphous state or too small in size to be detected by XRD analysis. In the case of Ce-modified catalyst, the strong peaks of $\mathrm{CeO}_{2}$ phase were confirmed in addition to $\mathrm{NiO}$ and $\mathrm{Al}_{2} \mathrm{O}_{3}$ phases. These results indicated that the sintering of $\mathrm{CeO}_{2}$ particles proceeded readily compared to other rare-earth compounds. In previous studies, the formation of $\mathrm{NiAl}_{2} \mathrm{O}_{4}$ spinel via the solid state reaction between $\mathrm{NiO}$ and $\mathrm{Al}_{2} \mathrm{O}_{3}$ was reported for $\mathrm{Ni} / \mathrm{Al}_{2} \mathrm{O}_{3}$ catalysts $[23,24]$. Thus, $\mathrm{NiAl}_{2} \mathrm{O}_{4}$ formation was expected in this study though it was difficult to distinguish the diffraction peaks of $\mathrm{NiAl}_{2} \mathrm{O}_{4}$ from those of $\mathrm{NiO}$ and $\mathrm{Al}_{2} \mathrm{O}_{3}$. After the reduction treatment at $600^{\circ} \mathrm{C}$, the Ni species was in the metallic state and the other phases remained unchanged for all the catalysts (not shown).

The specific surface area, pore volume, and mean pore diameter obtained by the BET method for the as-calcined catalysts are summarized in Table 1. For modified $\mathrm{Ni} / \mathrm{Al}_{2} \mathrm{O}_{3}$ catalysts, each parameter related to $\mathrm{Al}_{2} \mathrm{O}_{3}$ support was smaller than that of unmodified one. This implied that some of additive elements were precipitated in the pores of support. The surface area of Ce- and Sm-modified catalysts was relatively high, while that of Y- and La-modified catalysts showed the lowest value. Judging from XRD patterns, the dispersion states of rare-earth elements appear to be unrelated with the specific surface area. The CO pulse chemisorption measurement was performed after reduction at $600^{\circ} \mathrm{C}$ to determine the $\mathrm{Ni}$ surface area, Ni dispersion, and Ni particle size (see Table 1). These parameters were calculated based on the assumption that the stoichiometric ratio of adsorbed CO to Ni surface atom was 1:1. The Ni dispersion, Ni surface area, and Ni particle size of unmodified $\mathrm{Ni} / \mathrm{Al}_{2} \mathrm{O}_{3}$ catalyst were $3.50 \%, 2.05 \mathrm{~m}^{2}$ $\mathrm{g}^{-1}$, and $29 \mathrm{~nm}$, respectively. In previous reports, the addition of La or Ce elements to $\mathrm{Ni} / \mathrm{SBA}-15$ and $\mathrm{Ni} / \mathrm{Al}_{2} \mathrm{O}_{3}$ improved their Ni dispersion and lowered the particle size of 
$\mathrm{Ni}$ metal because of the interaction between additives and $\mathrm{Ni}$ particles. These additive effects were confirmed when the Ni particle size of the unmodified sample was ca. $5 \mathrm{~nm}$ [20-22]. Meanwhile, in this study, the surface area and particle size of Ni metal were slightly decremented and enlarged, respectively, by the addition of rare-earth elements other than La one. The size of Ni particles for the catalysts in this study was ca. $30 \mathrm{~nm}$, which was much larger than the reported values [20-22]. The Ni particle size would be one of the factors affecting the appearance of the additive effect.

\subsection{Reduction property of modified $\mathrm{Ni} / \mathrm{Al}_{2} \mathrm{O}_{3}$ catalysts}

The effect of rare-earth elements on the reduction behavior of modified $\mathrm{Ni} / \mathrm{Al}_{2} \mathrm{O}_{3}$ catalysts calcined at $500^{\circ} \mathrm{C}$ was investigated by TPR measurement. Fig. 2 shows the TPR profiles of unmodified and modified catalysts. For the $\mathrm{Ni} / \mathrm{Al}_{2} \mathrm{O}_{3}$ catalyst, two broad peaks were observed at ca. $580^{\circ} \mathrm{C}$ and $800^{\circ} \mathrm{C}$. The former and the latter were assigned to the reduction of oxidized nickel species weakly and strongly interacted with support, respectively. Since it was reported that $\mathrm{NiAl}_{2} \mathrm{O}_{4}$ is reduced at $750-825^{\circ} \mathrm{C}[23$, 24], a part of $\mathrm{H}_{2}$ consumption at around $800^{\circ} \mathrm{C}$ might be derived from the reduction of $\mathrm{NiAl}_{2} \mathrm{O}_{4}$. The addition of $\mathrm{Y}$ and La elements facilitated the reduction of oxidized nickel species, judging from a small peak at $450^{\circ} \mathrm{C}$. This implied an increase in the amount of oxidized nickel species weakly-interacted with $\mathrm{Al}_{2} \mathrm{O}_{3}$ support. For the Ce-modified catalyst, a small peak at $200-300^{\circ} \mathrm{C}$ and a sharp peak at $880^{\circ} \mathrm{C}$ appeared in addition to the broad peak confirmed at $400-800^{\circ} \mathrm{C}$. In the previous investigation, the reduction of bare $\mathrm{CeO}_{2}$ started from ca. $350^{\circ} \mathrm{C}$ [21], which was higher than the onset temperature of the small peak in this study. On the other hand, Takeguchi et al. reported that the spillover hydrogen could facilitate the reduction of $\mathrm{CeO}_{2}$ in the case of the $\mathrm{Pt} / \mathrm{CeO}_{2}$ catalyst [28]. Thus, there is a possibility that the small peak at $200-300^{\circ} \mathrm{C}$ for the Ce-modified catalyst is derived from the surface of $\mathrm{CeO}_{2}$ in the vicinity of Ni species, although it is difficult to identify the reduced species at this moment. According to the literature [21], the latter sharp peak at $880^{\circ} \mathrm{C}$ would be ascribable to the reduction of oxidized nickel species in $\mathrm{NiO}-\mathrm{CeO}_{2}$ solid solutions. Other additives did not affect the 
reduction behavior of $\mathrm{Ni} / \mathrm{Al}_{2} \mathrm{O}_{3}$ catalyst, indicating the interaction between $\mathrm{Ni}$ metal and $\mathrm{Al}_{2} \mathrm{O}_{3}$ support was almost the same as that for the unmodified catalyst.

\subsection{Catalytic performance of modified $\mathrm{Ni} / \mathrm{Al}_{2} \mathrm{O}_{3}$ catalysts}

Ammonia decomposition over the catalysts was investigated. The samples were calcined at $500^{\circ} \mathrm{C}$ and reduced at $600^{\circ} \mathrm{C}$ for $2 \mathrm{~h}$ prior to the activity evaluation. The catalytic performance at different temperatures for each catalyst is shown in Fig. 3. The ammonia conversion at $550^{\circ} \mathrm{C}$ extracted from Fig. 3 is also displayed in Fig. 4. The decomposition initiated from ca. $350^{\circ} \mathrm{C}$ and the ammonia conversion increased with temperature. It is apparent that the addition of rare-earth elements enhanced the ammonia conversion significantly. The order of promotion effect at $550^{\circ} \mathrm{C}$ was as follows, $\mathrm{La}>\mathrm{Nd}>\mathrm{Pr}>\mathrm{Y}>\mathrm{Sm}>\mathrm{Gd}>\mathrm{Eu}>\mathrm{Ce}$. The most active catalyst of La-modified $\mathrm{Ni} / \mathrm{Al}_{2} \mathrm{O}_{3}$ exhibited $92 \%$ of ammonia conversion at $550^{\circ} \mathrm{C}$. In the previous report for Ni/SBA-15 catalysts prepared by the deposit-precipitation method, the addition of $\mathrm{La}$ and $\mathrm{Ce}$ elements increased the catalytic activity for ammonia decomposition due to the enhancement of Ni dispersion [22]. In this study, however, the Ni surface area was not expanded for the modified catalysts other than the La-modified one as shown in Table 1 . Besides, the $\mathrm{Ni}-\mathrm{Al}_{2} \mathrm{O}_{3}$ interaction was scarcely changed by the additives as indicated in the TPR profiles (see Fig. 2). Therefore, it is considered that the improvement effect of rare-earth elements on the catalytic activity would be mainly attributable to the change in the physicochemical property of active sites.

\subsection{Desorption behavior of gas species over catalysts}

In order to clarify the effect of the additive elements on the desorption behavior of ammonia, hydrogen, and nitrogen, $\mathrm{NH}_{3}$-TPSR measurement was conducted for $\mathrm{Al}_{2} \mathrm{O}_{3}$ support and $\mathrm{Ni} / \mathrm{Al}_{2} \mathrm{O}_{3}$. The desorption profiles of ammonia $(\mathrm{m} / \mathrm{z}=16)$, hydrogen $(\mathrm{m} / \mathrm{z}=$ 2), and nitrogen $(\mathrm{m} / \mathrm{z}=28)$ for $\mathrm{Al}_{2} \mathrm{O}_{3}$ are shown in Fig. 5(a). A sharp desorption peak of ammonia was observed at $140^{\circ} \mathrm{C}$ together with a tail extending to ca. $600^{\circ} \mathrm{C}$. This peak would result from the desorption of ammonia adsorbed on acidic sites of $\mathrm{Al}_{2} \mathrm{O}_{3}$. The hydrogen desorption initiated at $120^{\circ} \mathrm{C}$ and was remarkable above $300^{\circ} \mathrm{C}$. The emission 
above $300^{\circ} \mathrm{C}$ would be mainly attributable to the hydrogen adsorbed on the $\mathrm{Al}_{2} \mathrm{O}_{3}$ surface during the reduction treatment because the hydrogen desorption started at ca. $300^{\circ} \mathrm{C}$ in the blank measurement without the ammonia adsorption step (not shown). In contrast, nitrogen was detected above $120^{\circ} \mathrm{C}$ with a constant intensity. Taking into consideration that the evolution of nitrogen molecule occurred only via the combinative desorption of nitrogen atoms derived from ammonia, the decomposition of adsorbed ammonia proceeded slightly on $\mathrm{Al}_{2} \mathrm{O}_{3}$ accompanied with the hydrogen desorption.

Fig. 5(b) shows the corresponding desorption profiles for $\mathrm{Ni} / \mathrm{Al}_{2} \mathrm{O}_{3}$ calcined at $500^{\circ} \mathrm{C}$. In the ammonia profile, a broad desorption process with two peaks at $150^{\circ} \mathrm{C}$ and $250^{\circ} \mathrm{C}$ was detected. The peak intensity ratio of the former to the latter was smaller than that observed for $\mathrm{Al}_{2} \mathrm{O}_{3}$, suggesting that the number of acidic sites weakly-interacting with ammonia relatively decreased by the loading of nickel. Two defined peaks of hydrogen desorption appeared at $170^{\circ} \mathrm{C}$ and $380^{\circ} \mathrm{C}$, which can be mainly ascribable to the hydrogen adsorbed on Ni surface via ammonia decomposition and on $\mathrm{Al}_{2} \mathrm{O}_{3}$ surface during the reduction treatment, respectively. The slightly high temperature of the latter peak of $380^{\circ} \mathrm{C}$, as compared to that observed on $\mathrm{Al}_{2} \mathrm{O}_{3}$, might indicate that hydrogen was adsorbed on the $\mathrm{Ni}$ surface strongly-interacting with $\mathrm{Al}_{2} \mathrm{O}_{3}$ such as the $\mathrm{Ni}-\mathrm{Al}_{2} \mathrm{O}_{3}$ interface. In response to hydrogen formation via ammonia decomposition, specific nitrogen desorption was confirmed in the temperature range of $240-440^{\circ} \mathrm{C}$. Nitrogen atoms would adsorb on the Ni surface more strongly than hydrogen atoms. It has been proposed by Verhaak et al. [25] that the formation of nickel nitride and its subsequent decomposition to metallic nickel and nitrogen proceeded above $300^{\circ} \mathrm{C}$ during the $\mathrm{NH}_{3}$-TPSR measurement over $\mathrm{Ni} / \mathrm{Al}_{2} \mathrm{O}_{3}$ catalyst as follows;

$$
2 \mathrm{Ni}_{3} \mathrm{~N} \rightleftharpoons 6 \mathrm{Ni}+\mathrm{N}_{2}
$$

Accordingly, the decomposition of nickel nitride might be responsible for a part of the evolution of nitrogen.

A series of $\mathrm{NH}_{3}$-TPSR measurements was also conducted for modified $\mathrm{Ni} / \mathrm{Al}_{2} \mathrm{O}_{3}$ catalysts calcined at $500^{\circ} \mathrm{C}$. The desorption profiles of ammonia, nitrogen, and hydrogen 
for modified catalysts are shown in Figs. 6, 7, and 8, respectively. For comparison, the results of $\mathrm{Ni} / \mathrm{Al}_{2} \mathrm{O}_{3}$ are also depicted. For modified catalysts, the ammonia desorption started at $110^{\circ} \mathrm{C}$ as in the case of the $\mathrm{Ni} / \mathrm{Al}_{2} \mathrm{O}_{3}$. On the other hand, the peak in a range of $200-400^{\circ} \mathrm{C}$ disappeared probably because a part of acidic sites on $\mathrm{Al}_{2} \mathrm{O}_{3}$ support was covered by the additives. The peak area ratio of nitrogen desorption at $110-220^{\circ} \mathrm{C}$ to that above $250^{\circ} \mathrm{C}$ increased by the addition of rare-earth elements. This suggested an increment in the ratio of nitrogen weakly-adsorbed on the catalyst. In the ammonia decomposition over Ru catalysts, it is well accepted that highly active catalyst releases nitrogen at lower temperature because the combinative desorption of nitrogen atoms over the catalyst is the rate-determining step [2]. Therefore, this lowering of nitrogen desorption temperature is preferable for the ammonia decomposition. On the other hand, the large nitrogen desorption peak at higher temperature positively shifted by ca. $10-20^{\circ} \mathrm{C}$ by the modification. A rise in the nitrogen desorption temperature is undesirable for the promotion of decomposition reaction. From these results, it is difficult to conclude at this moment whether the addition of rare-earth elements promotes the nitrogen desorption step or not. For the modified catalysts, the hydrogen desorption profiles mainly consisted of two processes at $100-250^{\circ} \mathrm{C}$ and above $300^{\circ} \mathrm{C}$. The desorption amount of hydrogen above $300^{\circ} \mathrm{C}$ decreased relative to that at $100-250^{\circ} \mathrm{C}$ by the modification. This implies a decrease in hydrogen species strongly-adsorbed on the catalyst. Previous reports suggested the negative effect of produced hydrogen on catalytic ammonia decomposition because it occupies the active sites for the reaction $[2,14,26,27]$. Therefore, the rare-earth elements are effective for the suppression of hydrogen inhibition over $\mathrm{Ni} / \mathrm{Al}_{2} \mathrm{O}_{3}$ catalyst. Considering that the chemisorption energy of hydrogen with nickel depends on the adsorption sites of nickel surface [29], the rare-earth elements might alter the surface structure of Ni particles and lower the number of the sites strongly-bonding with hydrogen atoms. Besides, it has been proposed that the additives located at the metal-support interface prevent the spillover of hydrogen from metallic surface towards the support surface [30, 31]. As mentioned in Fig. 5, it was expected that the produced hydrogen adsorbed more strongly onto the $\mathrm{Ni}-\mathrm{Al}_{2} \mathrm{O}_{3}$ interface than onto the $\mathrm{Ni}$ surface. Thus, in this study, the rare-earth 
oxides located around $\mathrm{Ni}$ particles could inhibit the diffusion of hydrogen atoms from $\mathrm{Ni}$ surface to the interface, leading to the significant decrease in the fraction of hydrogen desorbed at high temperature in Fig. 8.

From the evaluation of catalytic performance and $\mathrm{NH}_{3}$-TPSR measurement, the alleviation of hydrogen poisoning by rare-earth elements should be responsible for the promotion of ammonia decomposition. However, it was difficult to entirely correlate the order of catalytic activity with the hydrogen desorption temperature among the modified catalysts.

\subsection{Influence of pretreatment conditions on the catalytic activity of La-modified} $\mathrm{Ni} / \mathrm{Al}_{2} \mathrm{O}_{3}$ catalyst

As shown in Fig. 3, the La-modified catalyst exhibited the highest activity among the catalysts studied. Then, the optimal pretreatment conditions, calcination temperature and reduction temperature, were investigated in order to improve the activity of the catalyst. In this study, the calcination temperature was changed in the range of $400^{\circ} \mathrm{C}-800^{\circ} \mathrm{C}$. The samples calcined below $300^{\circ} \mathrm{C}$ were not evaluated because it was confirmed from XRD analysis that the starting material did not decompose completely (not shown). Fig. 9 illustrates XRD patterns for La-modified catalysts calcined at various temperatures. The peak intensity ratio of $\mathrm{NiO}$ phase to $\mathrm{Al}_{2} \mathrm{O}_{3}$ phase decreased with a rise in calcination temperature. After calcination at $800^{\circ} \mathrm{C}$, the lines ascribable to $\mathrm{NiO}$ phase at $2 \theta=43$ and $63^{\circ}$ disappeared, while the intensity of the peak at $2 \theta=37^{\circ}$ strengthened. Since the diffraction peaks of $\mathrm{NiO}, \mathrm{Al}_{2} \mathrm{O}_{3}$, and $\mathrm{NiAl}_{2} \mathrm{O}_{4}$ phases overlapped at $2 \theta=37^{\circ}$, the change in this peak suggested a growth of $\mathrm{NiAl}_{2} \mathrm{O}_{4}$ phase in the sample. On the other hand, the characteristic peaks of La element were not confirmed for all samples, indicating that the La species remained highly dispersed in the range of $400^{\circ} \mathrm{C}-800^{\circ} \mathrm{C}$.

TPR measurement was conducted to study the effect of calcination temperature on the reduction behavior of La-modified catalysts (see Fig. 10). A broad peak was observed in the range of $200-850^{\circ} \mathrm{C}$ for the sample calcined at $400^{\circ} \mathrm{C}$. With a rise in the calcination temperature, the reduction peak shifted to higher temperature. In response to 
this change, the hydrogen consumption amount at $800-900^{\circ} \mathrm{C}$ increased. When the sample was calcined at $800^{\circ} \mathrm{C}$, only one peak was detected at ca. $850^{\circ} \mathrm{C}$, which was similar to the case of $\mathrm{NiAl}_{2} \mathrm{O}_{4}[23,24]$. A series of change in reduction profiles suggests that the agglomeration of $\mathrm{NiO}$ particles and the formation of $\mathrm{NiAl}_{2} \mathrm{O}_{4}$ proceed simultaneously with temperature; in other words, oxidized nickel species exist in the form of $\mathrm{NiAl}_{2} \mathrm{O}_{4}$ as well as $\mathrm{NiO}$, of which component ratio is determined by the calcination temperature. This result agreed well with XRD patterns in Fig. 9.

Fig. 11 shows the ammonia conversion at $550^{\circ} \mathrm{C}$ and $\mathrm{Ni}$ surface area of La-modified catalysts calcined at various temperatures. All catalysts were reduced at $600^{\circ} \mathrm{C}$ for $2 \mathrm{~h}$ prior to the measurements. The variation in ammonia conversion against the calcination temperature corresponded well with that in $\mathrm{Ni}$ surface area. The calcination temperatures at $400-600^{\circ} \mathrm{C}$ scarcely affected the catalytic activity for the ammonia decomposition, while the catalyst calcined above $700^{\circ} \mathrm{C}$ exhibited lower conversion. The Ni surface area decreased with an increase in calcination temperature mainly due to the sintering. The Ni particle size estimated by CO adsorption amount was more than $100 \mathrm{~nm}$ when the calcination temperature was above $700^{\circ} \mathrm{C}$. Besides, as shown in Fig. 10, the high calcination temperature led to an increase in the onset temperature for the reduction of oxidized nickel species. This means the amount of reducible nickel species below $600^{\circ} \mathrm{C}$ was decremented with a rise in calcination temperature, resulting in a decrease of $\mathrm{Ni}$ surface area. Therefore, the Ni dispersion and the ratio of reducible nickel species below $600^{\circ} \mathrm{C}$ are important factors for the catalytic activity.

Next, the influence of reduction temperature on Ni surface area and the catalytic activity was investigated for the La-modified catalyst calcined at $400^{\circ} \mathrm{C}$, which was the most active one as indicated in Fig. 11. The CO pulse measurement was carried out after reduction at various temperatures for 2 h. Table 2 summarizes the $\mathrm{Ni}$ dispersion, $\mathrm{Ni}$ surface area, and $\mathrm{Ni}$ particle size. The catalyst reduced at $500^{\circ} \mathrm{C}$ showed the highest $\mathrm{Ni}$ surface area as well as Ni dispersion. Fig. 12 shows the ammonia conversion for the La-modified catalysts reduced at $400^{\circ} \mathrm{C}-800^{\circ} \mathrm{C}$. At the reaction temperatures below $500^{\circ} \mathrm{C}$, the order in ammonia conversion against the reduction temperatures was as follows, $500^{\circ} \mathrm{C}>600^{\circ} \mathrm{C}>400^{\circ} \mathrm{C}>700^{\circ} \mathrm{C}>800^{\circ} \mathrm{C}$. This order agreed with that in $\mathrm{Ni}$ 
surface area. In contrast, when the reaction temperature was above $550^{\circ} \mathrm{C}$, the order in ammonia conversion changed to $600^{\circ} \mathrm{C}>500^{\circ} \mathrm{C}>700^{\circ} \mathrm{C}>400^{\circ} \mathrm{C}>800^{\circ} \mathrm{C}$. This might reflect the continuous reduction in $\mathrm{Ni}$ surface area during the test for the catalysts reduced at $400^{\circ} \mathrm{C}$ and $500^{\circ} \mathrm{C}$.

Throughout this investigation on the optimal pretreatment condition, it was clarified that the Ni dispersion state is an important factor for the superior catalyst. The lowering of calcination temperature was effective for the suppression of the sintering of oxidized nickel species and solid state reaction between $\mathrm{NiO}$ and $\mathrm{Al}_{2} \mathrm{O}_{3}$. On the other hand, the reduction treatment at low temperature was not necessarily beneficial to the catalytic activity because the amount of reducible nickel species was small and the aggregation of Ni particles proceeded during the test at high temperature. Therefore, in this study, the reduction treatment at $600^{\circ} \mathrm{C}$ will be appropriate for the ammonia decomposition over the La-modified catalyst.

The stability test was conducted in the range of $600^{\circ} \mathrm{C}-700^{\circ} \mathrm{C}$ for the La-modified catalyst calcined at $400^{\circ} \mathrm{C}$ and reduced at $600^{\circ} \mathrm{C}$ (see Fig. 13). Ammonia conversion for this catalyst remained unchanged at $700^{\circ} \mathrm{C}$ over $15 \mathrm{~h}$. Additionally, the conversion at $600^{\circ} \mathrm{C}$ was almost the same before and after the operation at $700^{\circ} \mathrm{C}$. This result implied that the sample prepared in this work was highly stable.

\subsection{Kinetics analysis}

The kinetics analysis was conducted for the modified and unmodified $\mathrm{Ni} / \mathrm{Al}_{2} \mathrm{O}_{3}$ catalysts subjected to calcination at $400^{\circ} \mathrm{C}$ and subsequent reduction treatment at $600^{\circ} \mathrm{C}$. The reaction rate $(r)$ is determined by using the partial pressures of ammonia $\left(P_{\mathrm{NH} 3}\right)$, nitrogen $\left(P_{\mathrm{N} 2}\right)$, and hydrogen $\left(P_{\mathrm{H} 2}\right)$ as follows;

$$
r=k P_{\mathrm{NH} 3}^{\alpha} P_{\mathrm{N} 2}^{\beta} P_{\mathrm{H} 2}^{\gamma}
$$

where $k$ is a reaction rate constant, and $\alpha, \beta$, and $\gamma$ are reaction orders.

First, the catalytic test was carried out at $450^{\circ} \mathrm{C}$ by varying the concentration of nitrogen ( $\mathrm{NH}_{3}$ : 30vol.\%, $\mathrm{N}_{2}: 10-30 \mathrm{vol} . \%$, and Ar balance) to confirm the effect of 
nitrogen partial pressure for the La-modified and unmodified samples (see Fig. 14). The reaction order with respect to nitrogen was almost zero for both catalysts (the $\beta$ values for the unmodified and La-modified samples were 0.005 and -0.006 , respectively). This indicates that the reaction rate was independent of the partial pressure of nitrogen. This result was consistent with previous reports [26, 27]. Accordingly the $P_{\mathrm{N} 2}{ }^{\beta}$ in the power law equation could be neglected, and Eq. (4) is simplified by using the partial pressures of ammonia and hydrogen;

$$
r=k^{\prime} P_{\mathrm{NH} 3}{ }^{\alpha} P_{\mathrm{H} 2}{ }^{\gamma}
$$

where $k^{\prime}$ is a reaction rate constant.

Next, the influence of ammonia and hydrogen pressures was evaluated for the modified and unmodified catalysts. Fig. 14 also displays the reaction rate against ammonia and hydrogen partial pressures for the La-modified and unmodified samples ( $\mathrm{NH}_{3}: 10-30 \mathrm{vol} . \%, \mathrm{H}_{2}: 10-30 \mathrm{vol} . \%$, and Ar balance), and Table 3 summarizes the $\mathrm{NH}_{3}$ conversion, and the reaction orders of ammonia and hydrogen determined by Eq. (5) for all samples investigated. The ammonia order $(\alpha)$ was positive for all the catalysts, and the value of unmodified catalyst was smaller than those of modified ones. On the other hand, the hydrogen order $(\gamma)$ was negative, indicating that hydrogen inhibited the ammonia decomposition. In a number of studies, it is accepted that the large and negative value of $\gamma$ implies that hydrogen strongly-adsorbed on the catalyst gives rise to the lowering of catalytic activity [2, 14, 26, 27]. In this study, the absolute value of $\gamma$ in $\mathrm{Ni} / \mathrm{Al}_{2} \mathrm{O}_{3}$ catalyst decreased by the addition of rare-earth elements. Thus, it can be concluded that the rare-earth elements could weaken the negative effect of hydrogen on the catalytic ammonia decomposition. This result corresponds to the presumption obtained from the comparison of hydrogen desorption behavior for the unmodified and modified catalysts (see Fig. 8). Besides, the absolute value of hydrogen reaction order was the smallest for the La-modified sample, suggesting the hydrogen poisoning was significantly alleviated over this catalyst. This would be one of the important reasons 
that the La species exhibited the highest promotion effect among the rare-earth elements investigated. 


\section{Conclusions}

The ammonia decomposition over $\mathrm{Ni} / \mathrm{Al}_{2} \mathrm{O}_{3}$ catalysts modified by rare-earth elements was investigated to elucidate the effect of additives on the catalytic activity. The addition of rare-earth elements promoted the decomposition reaction. Among the modified catalysts prepared, the La-modified catalyst exhibited the highest activity. For the La-modified catalyst, the optimal calcination and reduction temperatures were $400^{\circ} \mathrm{C}$ and $600^{\circ} \mathrm{C}$, respectively.

The Ni dispersion was not improved by the addition of rare-earth elements other than La one. This implied that the high catalytic activity for the modified catalysts was not attributed to the change of $\mathrm{Ni}$ surface area. The kinetics study of ammonia decomposition over the unmodified and modified catalysts suggested the hydrogen inhibition against the decomposition over all the catalysts. The comparison in the desorption behavior of hydrogen has revealed the amount of hydrogen strongly-adsorbed on the catalyst was reduced by the modification. Therefore, it was concluded that the addition of rare-earth elements was effective for the suppression of hydrogen inhibition phenomenon.

\section{Acknowledgements}

This work was supported by Council for Science, Technology and Innovation (CSTI), Cross-ministerial Strategic Innovation Promotion Program (SIP), “energy carrier” (Funding agency: JST). 


\section{References}

[1] T.V. Choudhary, D.W. Goodman, Catal. Today 77 (2002) 65-78.

[2] S.F. Yin, B.Q. Xu, X.P. Zhou, C.T. Au, Appl. Catal. A: Gen. 277 (2004) 1-9.

[3] J.C. Ganley, F.S. Thomas, E.G. Seebauer, R.I. Masel, Catal. Lett. 96 (2004) 117-122.

[4] R. Pelka, I. Moszyńska, W. Arabczyk, Catal. Lett. 128 (2009) 72-76.

[5] W. Zheng, T.P. Cotter, P. Kaghazchi, T. Jacob, B. Frank, K. Schlichte, W. Zhang, D.S. Su, F. Schüth, R. Schlögl, J. Am. Chem. Soc. 135 (2013) 3458-3464.

[6] Z. Zhao, H. Zou, W. Lin, J. Rare Earths 31 (2013) 247-250.

[7] B. Lorenzut, T. Montini, M. Bevilacqua1, P. Fornasiero, Appl. Catal. B: Environ. 125 (2012) 409-417.

[8] S.F. Yin, Q.H. Zhang, B.Q. Xu, W.X. Zhu, C.F. Ng, C.T. Au, J. Catal. 224 (2004) 384-396.

[9] S.J. Wang, S.F. Yin, L. Li, B.Q. Xu, C.F. Ng, C.T. Au, Appl. Catal. B: Environ. 52 (2004) 287-299.

[10] K. Nagaoka, K. Honda, M. Ibuki, K. Sato, Y. Takita, Chem. Lett. 39 (2010) 918-919.

[11] A.D. Carlo, L. Vecchione, Z.D. Prete, Int. J. Hydrogen Energy 39 (2014) 808-814.

[12] D. Szmigiel, W. Raróg-Pilecka, E. Miśkiewicz, Z. Kaszkur, Z. Kowalczyk, Appl. Catal. A: Gen. 264 (2004) 59-63.

[13] S.F. Yin, B.Q. Xu, S.J. Wang, C.T. Au, J. Catal. 301 (2006) 202-210.

[14] F. Hayashi, Y. Toda, Y. Kanie, M. Kitano, Y. Inoue, T. Yokoyama, M. Hara, H. Hosono, Chem. Sci. 4 (2013) 3124-3130.

[15] L. Yao, T. Shi, Y.X. Li, J. Zhao, W.J. Ji, C.T. Au, Catal. Today 164 (2011) 112-118.

[16] L.H. Yao, Y.X. Li, J. Zhao, W.J. Ji, C.T. Au, Catal. Today 158 (2010) 401-408.

[17] X.K. Li, W.J. Ji, J. Zhao, S.J. Wang, C.T. Au, J. Catal. 236 (2005) 181-189.

[18] Q.F. Deng, H. Zhang, X.X. Hou, T.Z. Ren, Z.Y. Yuan, Int. J. Hydrogen Energy 37 (2012) 15901-15907.

[19] H. Muroyama, C. Saburi, T. Matsui, K. Eguchi, Appl. Catal. A: Gen. 443-444 (2012) 119-124. 
[20] J. Zhang, H. Xu, X. Jin, Q. Ge, W. Li, Appl. Catal. A: Gen. 290 (2005) 87-96.

[21] W. Zheng, J. Zhang, Q. Ge, H. Xu, W. Li, Appl. Catal. B: Environ. 80 (2008) 98-105.

[22] H. Liu, H. Wang, J. Shen, Y. Sun, Z. Liu, Appl. Catal. Today 131 (2008) 444-449.

[23] C.Y. Li, H.J. Zhang, Z.Q. Chen, Appl. Surf. Sci. 266 (2013) 17-21.

[24] Z. Boukha, C. Jiménez-González, B. Rivas, J.R. González-Velasco, J.I. Gutiérrez-Ortiz, R. López-Fonseca, Appl. Catal. B: Environ. 158-159 (2014) 190-201.

[25] M.J.F.M. Verhaak, A.J. van Dillen, J.W. Geus, Appl.Catal. A: Gen. 105 (1993) 251-269.

[26] J. Zhang, H. Xu, W. Li, Appl. Catal. A: Gen. 296 (2005) 257-267.

[27] A.S. Chellappa, C.M. Fischer, W.J. Thomson, Appl. Catal. A: Gen. 227 (2002) 231-240.

[28] T. Takeguchi, S. Manabe, R. Kikuchi, K. Eguchi, T. Kanazawa, S. Matsumoto, W. Ueda, Appl. Catal. A: Gen. 293 (2005) 91-96.

[29] T.H. Upton, W.A. Goddard, Phys. Rev. Lett. 42 (1979) 472-476.

[30] Z. Kowalczyk, M. Krukowski, W. Raróg-Pilecka, D. Szmigiel, J. Zielinski, Appl. Catal. A: Gen. 248 (2003) 67-73.

[31] F.R. García-García, A. Guerrero-Ruiz, I. Rodríguez-Ramos, A. Goguet, S.O. Shekhtman, C. Hardacre, Phys. Chem. Chem. Phys. 13 (2011) 12892-12899. 


\section{Figure captions}

Fig. 1 XRD patterns of $M$-modified $\mathrm{Ni} / \mathrm{Al}_{2} \mathrm{O}_{3}(M=\mathrm{Y}$, La, Ce, Pr, Nd, Sm, Eu, Gd) and $\mathrm{Ni} / \mathrm{Al}_{2} \mathrm{O}_{3}$ catalysts after calcination at $500^{\circ} \mathrm{C}$.

Fig. 2 TPR profiles of $M$-modified $\mathrm{Ni} / \mathrm{Al}_{2} \mathrm{O}_{3}(M=\mathrm{Y}, \mathrm{La}, \mathrm{Ce}, \mathrm{Pr}, \mathrm{Nd}, \mathrm{Sm}, \mathrm{Eu}, \mathrm{Gd})$ and $\mathrm{Ni} / \mathrm{Al}_{2} \mathrm{O}_{3}$ catalysts after calcination at $500^{\circ} \mathrm{C}$ in $4 \% \mathrm{H}_{2} / \mathrm{Ar}$ under a heating rate of $10^{\circ} \mathrm{C}$ $\min ^{-1}$.

Fig. 3 Ammonia conversion for ammonia decomposition over $M$-modified $\mathrm{Ni} / \mathrm{Al}_{2} \mathrm{O}_{3}(M$ $=\mathrm{Y}, \mathrm{La}, \mathrm{Ce}, \mathrm{Pr}, \mathrm{Nd}, \mathrm{Sm}, \mathrm{Eu}, \mathrm{Gd})$ and $\mathrm{Ni} / \mathrm{Al}_{2} \mathrm{O}_{3}$ catalysts after calcination at $500^{\circ} \mathrm{C}$.

Fig. 4 Ammonia conversion at $550^{\circ} \mathrm{C}$ for ammonia decomposition over $M$-modified $\mathrm{Ni} / \mathrm{Al}_{2} \mathrm{O}_{3}(M=\mathrm{Y}, \mathrm{La}, \mathrm{Ce}, \mathrm{Pr}, \mathrm{Nd}, \mathrm{Sm}, \mathrm{Eu}, \mathrm{Gd})$ and Ni/ $\mathrm{Al}_{2} \mathrm{O}_{3}$ catalysts after calcination at $500^{\circ} \mathrm{C}$.

Fig. 5 Ammonia, hydrogen, and nitrogen desorption profiles for (a) $\mathrm{Al}_{2} \mathrm{O}_{3}$ and (b) $\mathrm{Ni} / \mathrm{Al}_{2} \mathrm{O}_{3}$ catalyst obtained by $\mathrm{NH}_{3}$-TPSR measurement in He flow under a heating rate of $10^{\circ} \mathrm{C} \mathrm{min}^{-1}$.

Fig. 6 Ammonia desorption profiles for (a) Y-, (b) La-, (c) Ce-, (d) Gd-modified, and (e) unmodified $\mathrm{Ni} / \mathrm{Al}_{2} \mathrm{O}_{3}$ catalysts obtained by $\mathrm{NH}_{3}$-TPSR measurement in He flow under a heating rate of $10^{\circ} \mathrm{C} \mathrm{min}^{-1}$.

Fig. 7 Nitrogen desorption profiles for (a) Y-, (b) La-, (c) Ce-, (d) Gd-modified, and (e) unmodified $\mathrm{Ni} / \mathrm{Al}_{2} \mathrm{O}_{3}$ catalysts obtained by $\mathrm{NH}_{3}$-TPSR measurement in He flow under a heating rate of $10^{\circ} \mathrm{C} \mathrm{min}^{-1}$. 
Fig. 8 Hydrogen desorption profiles for (a) Y-, (b) La-, (c) Ce-, (d) Gd-modified, and (e) unmodified $\mathrm{Ni} / \mathrm{Al}_{2} \mathrm{O}_{3}$ catalysts obtained by $\mathrm{NH}_{3}$-TPSR measurement in He flow under a heating rate of $10^{\circ} \mathrm{C} \mathrm{min}^{-1}$.

Fig. 9 XRD patterns of La-modified $\mathrm{Ni} / \mathrm{Al}_{2} \mathrm{O}_{3}$ catalysts calcined at (a) $400^{\circ} \mathrm{C}$, (b) $500^{\circ} \mathrm{C}$, (c) $600^{\circ} \mathrm{C}$, (d) $700^{\circ} \mathrm{C}$, and (e) $800^{\circ} \mathrm{C}$.

Fig. 10 TPR profiles of La-modified $\mathrm{Ni} / \mathrm{Al}_{2} \mathrm{O}_{3}$ catalysts calcined at (a) $400^{\circ} \mathrm{C}$, (b) $500^{\circ} \mathrm{C}$, (c) $600^{\circ} \mathrm{C}$, (d) $700^{\circ} \mathrm{C}$, and (e) $800^{\circ} \mathrm{C}$ in $4 \% \mathrm{H}_{2} / \mathrm{Ar}$ under a heating rate of $10^{\circ} \mathrm{C} \mathrm{min}^{-1}$.

Fig. 11 Ammonia conversion at $550^{\circ} \mathrm{C}$ and $\mathrm{Ni}$ surface area as a function of calcination temperature for La-modified $\mathrm{Ni} / \mathrm{Al}_{2} \mathrm{O}_{3}$ catalyst.

Fig. 12 Ammonia conversion for ammonia decomposition over La-modified $\mathrm{Ni} / \mathrm{Al}_{2} \mathrm{O}_{3}$ catalyst reduced at $400^{\circ} \mathrm{C}-800^{\circ} \mathrm{C}$.

Fig. 13 Time course of ammonia conversion at $600^{\circ} \mathrm{C}-700^{\circ} \mathrm{C}$ for the La-modified $\mathrm{Ni} / \mathrm{Al}_{2} \mathrm{O}_{3}$ catalyst calcined at $400^{\circ} \mathrm{C}$ and reduced at $600^{\circ} \mathrm{C}$.

Fig. 14 Reaction rate for ammonia decomposition over $\mathrm{Ni} / \mathrm{Al}_{2} \mathrm{O}_{3}$ (open symbols) and La-modified $\mathrm{Ni} / \mathrm{Al}_{2} \mathrm{O}_{3}$ (closed symbols) catalysts as a function of nitrogen, hydrogen, and ammonia partial pressures. The catalysts were calcined at $400^{\circ} \mathrm{C}$ and reduced at $600^{\circ} \mathrm{C}$. 
Table 1 Physical properties for the modified and unmodified $\mathrm{Ni} / \mathrm{Al}_{2} \mathrm{O}_{3}$ catalysts

\begin{tabular}{ccccccc}
\hline $\begin{array}{c}\text { Additive } \\
\text { elements }\end{array}$ & $\begin{array}{c}\text { BET surface } \\
\text { area } \\
\left(\mathrm{m}^{2} \mathrm{~g}^{-1}\right)\end{array}$ & $\begin{array}{c}\text { Pore volume } \\
\left(\mathrm{cm}^{3} \mathrm{~g}^{-1}\right)\end{array}$ & $\begin{array}{c}\text { Pore diameter } \\
(\mathrm{nm})\end{array}$ & $\begin{array}{c}\text { Ni dispersion } \\
(\%)\end{array}$ & $\begin{array}{c}\text { Ni surface } \\
\text { area } \\
\left(\mathrm{m}^{2} \mathrm{~g}_{\text {sample }}{ }^{-1}\right)\end{array}$ & $\begin{array}{c}\text { Ni particle } \\
\text { size } \\
(\mathrm{nm})\end{array}$ \\
\hline $\mathrm{Y}$ & 109 & 0.32 & 11.8 & 3.39 & 1.99 & 30 \\
$\mathrm{La}$ & 109 & 0.46 & 17.1 & 3.57 & 2.09 & 28 \\
$\mathrm{Ce}$ & 119 & 0.47 & 15.6 & 3.43 & 2.01 & 29 \\
$\mathrm{Pr}$ & 113 & 0.48 & 16.9 & 2.98 & 1.73 & 34 \\
$\mathrm{Nd}$ & 110 & 0.44 & 16.0 & 3.44 & 2.02 & 30 \\
$\mathrm{Sm}$ & 134 & 0.49 & 14.7 & 3.06 & 1.80 & 33 \\
$\mathrm{Eu}$ & 112 & 0.40 & 14.3 & 3.48 & 2.03 & 29 \\
$\mathrm{Gd}$ & 113 & 0.42 & 14.7 & 3.45 & 2.02 & 29 \\
$\mathrm{None}$ & 140 & 0.62 & 17.8 & 3.50 & 2.05 & 29 \\
\hline
\end{tabular}




\section{Table 2}

$\mathrm{Ni}$ surface area, $\mathrm{Ni}$ dispersion, and $\mathrm{Ni}$ particle size for La-modified $\mathrm{Ni} / \mathrm{Al}_{2} \mathrm{O}_{3}$ catalysts reduced at $400^{\circ} \mathrm{C}-800^{\circ} \mathrm{C}$

\begin{tabular}{cccc}
\hline $\begin{array}{c}\text { Reduction } \\
\text { temperature } \\
\left({ }^{\circ} \mathrm{C}\right)\end{array}$ & $\begin{array}{c}\text { Ni dispersion } \\
(\%)\end{array}$ & $\begin{array}{c}\text { Ni surface area } \\
\left(\mathrm{m}^{2} \mathrm{~g}_{\text {sample }}{ }^{-1}\right)\end{array}$ & $\begin{array}{c}\text { Ni particle size } \\
(\mathrm{nm})\end{array}$ \\
\hline 400 & 3.5 & 2.03 & 29 \\
500 & 4.5 & 2.66 & 22 \\
600 & 3.6 & 2.12 & 28 \\
700 & 2.6 & 1.50 & 39 \\
800 & 1.5 & 0.93 & 34 \\
\hline
\end{tabular}


Table 3

$\mathrm{NH}_{3}$ conversion and reaction order in Eq. (5) for ammonia decomposition over the modified and unmodified $\mathrm{Ni} / \mathrm{Al}_{2} \mathrm{O}_{3}$ catalysts

\begin{tabular}{|c|c|c|c|}
\hline \multirow{2}{*}{$\begin{array}{l}\text { Additive } \\
\text { elements }^{a}\end{array}$} & \multirow{2}{*}{$\begin{array}{c}\mathrm{NH}_{3} \\
\text { conversion }(\%)^{b}\end{array}$} & \multicolumn{2}{|c|}{ Reaction order ${ }^{c}$} \\
\hline & & $\alpha$ & $\gamma$ \\
\hline $\mathrm{Y}$ & 18.8 & 0.89 & -0.74 \\
\hline $\mathrm{La}$ & 20.2 & 0.60 & -0.72 \\
\hline $\mathrm{Ce}$ & 15.4 & 0.44 & -0.82 \\
\hline $\mathrm{Pr}$ & 19.7 & 0.87 & -0.75 \\
\hline $\mathrm{Nd}$ & 19.7 & 0.74 & -0.84 \\
\hline $\mathrm{Sm}$ & 18.2 & 0.43 & -0.78 \\
\hline $\mathrm{Eu}$ & 15.9 & 0.44 & -0.78 \\
\hline $\mathrm{Gd}$ & 15.8 & 0.68 & -0.87 \\
\hline None & 10.0 & 0.48 & -0.97 \\
\hline
\end{tabular}

${ }^{a}$ Catalysts were calcined at $400^{\circ} \mathrm{C}$ and reduced at $600^{\circ} \mathrm{C}$.

${ }^{b}$ Determined at $450^{\circ} \mathrm{C}$ and a space velocity of $6,000 \mathrm{l} \mathrm{kg}^{-1} \mathrm{~h}^{-1}\left(\mathrm{NH}_{3}: 100 \mathrm{vol} . \%\right)$.

${ }^{c}$ Determined at $450^{\circ} \mathrm{C}$ and a space velocity of $10,000 \mathrm{l} \mathrm{kg}^{-1} \mathrm{~h}^{-1}\left(\mathrm{NH}_{3}: 10-30 \mathrm{vol} . \%, \mathrm{H}_{2}\right.$ : 10-30vol.\%, and Ar balance). 


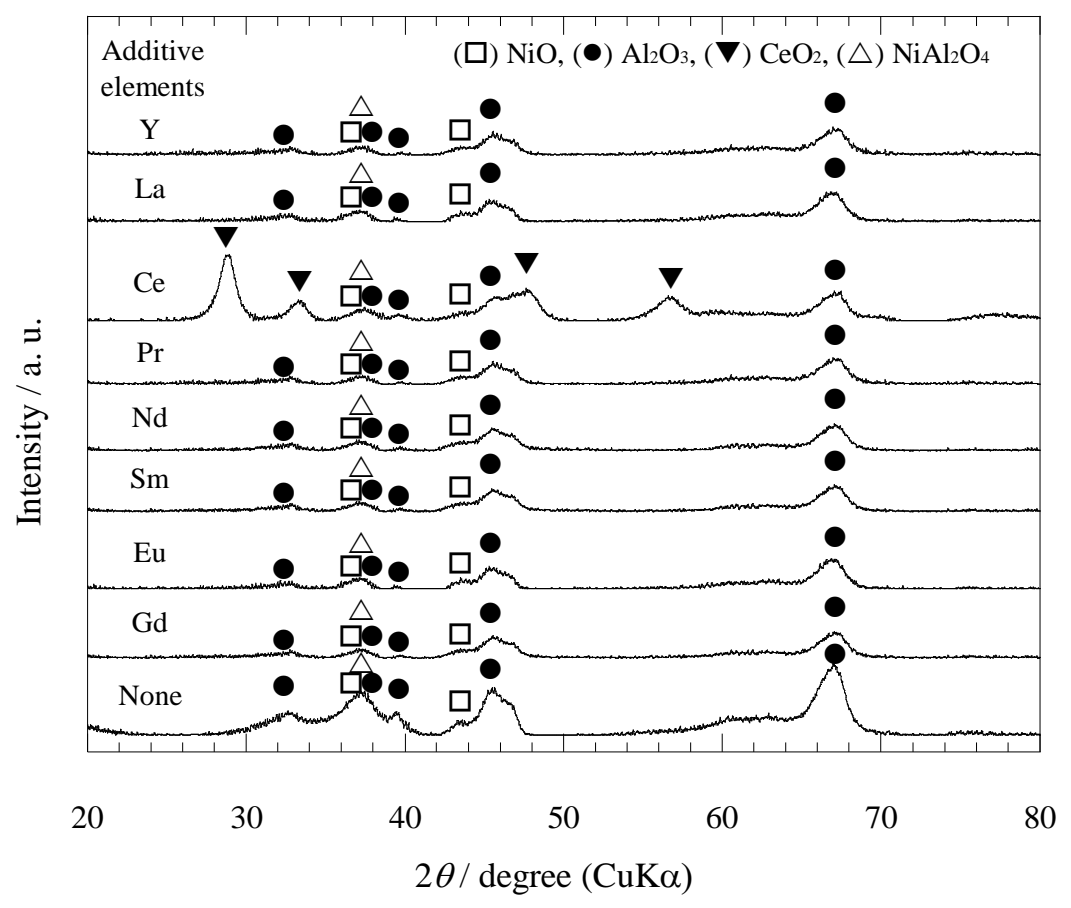

Fig. 1. K. Okura et al. 


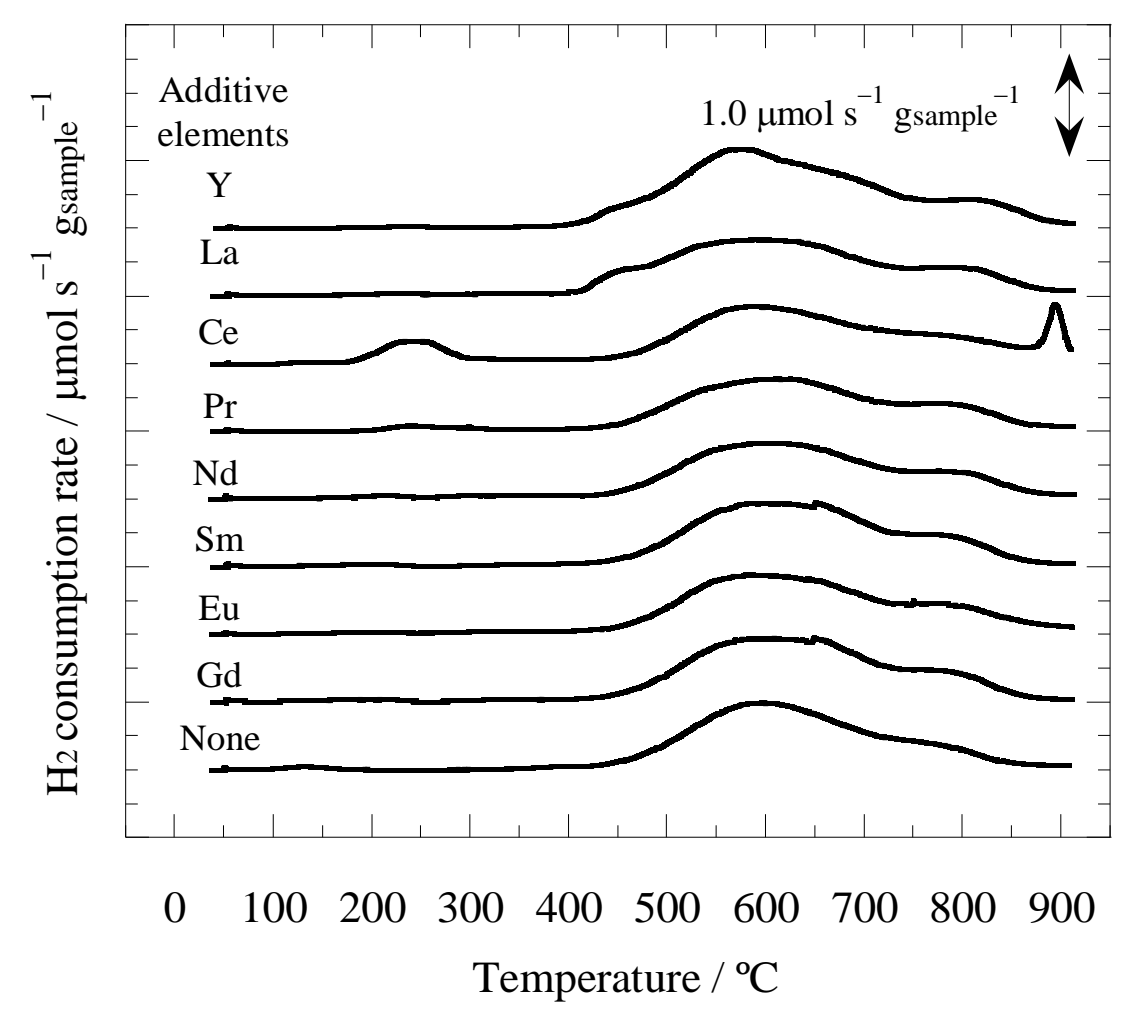

Fig. 2. K. Okura et al. 


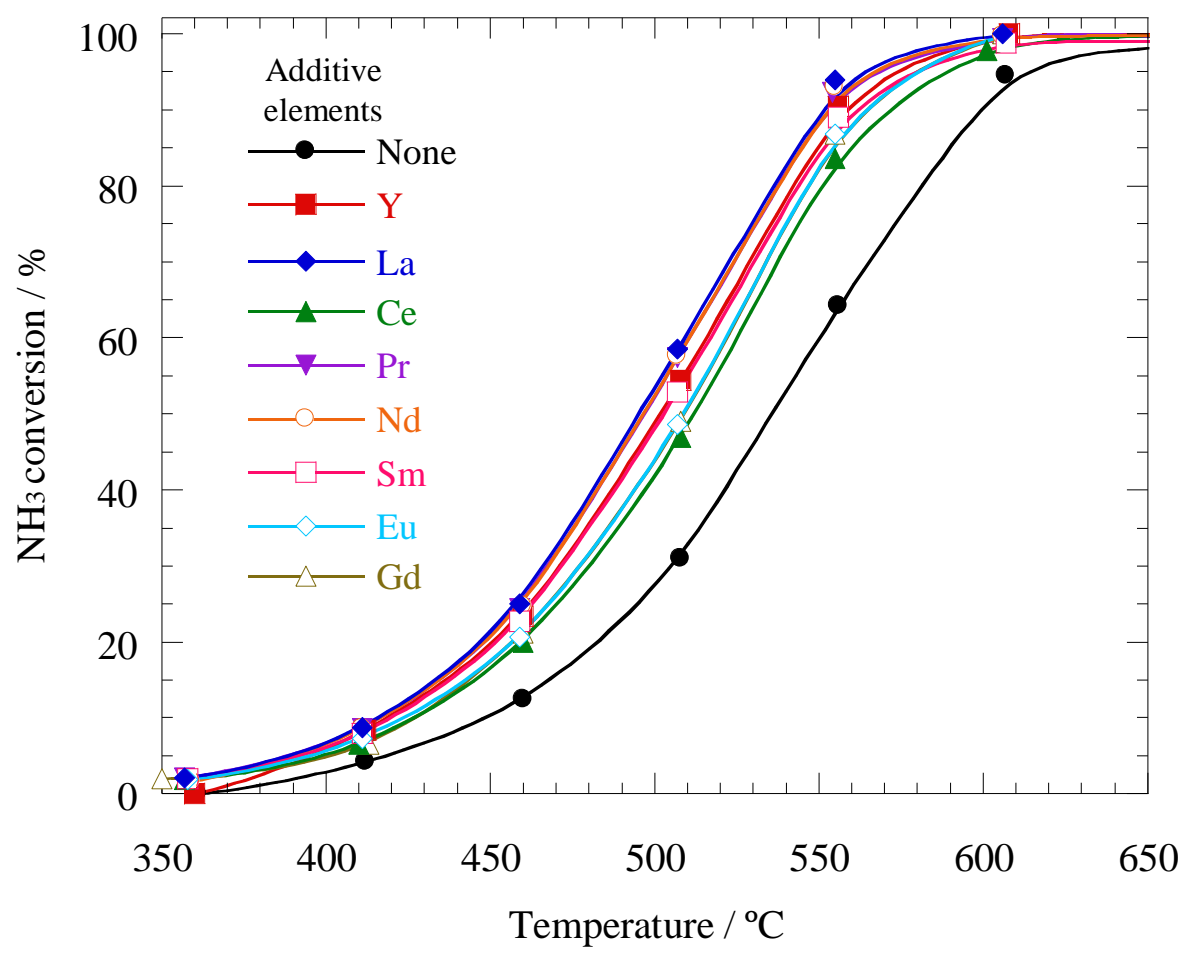

Fig. 3. K. Okura et al. 


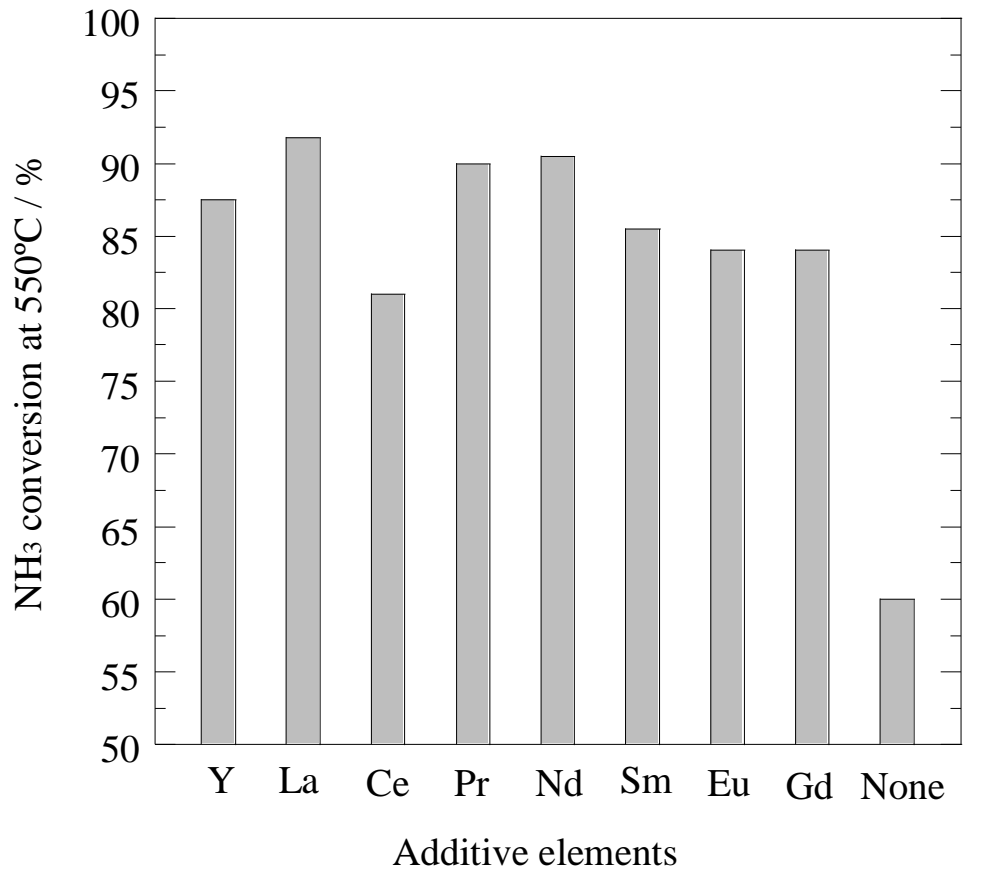

Fig. 4. K. Okura et al. 
(a) $\mathrm{Al}_{2} \mathrm{O}_{3}$

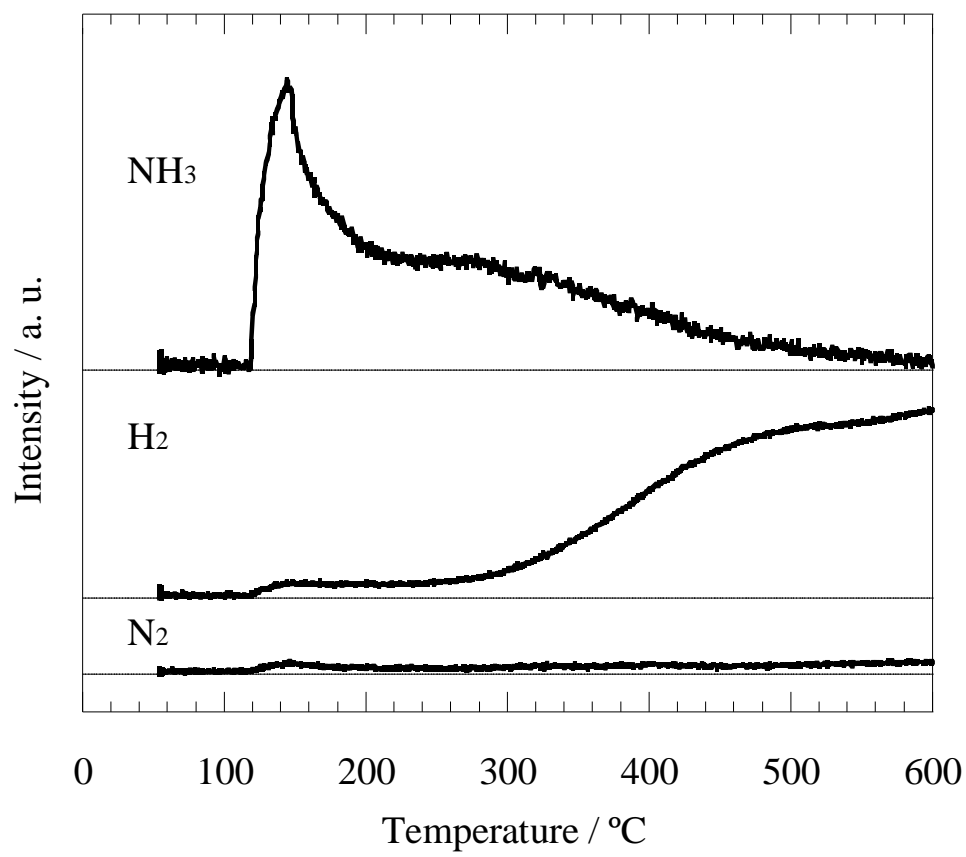

(b) $\mathrm{Ni} / \mathrm{Al}_{2} \mathrm{O}_{3}$

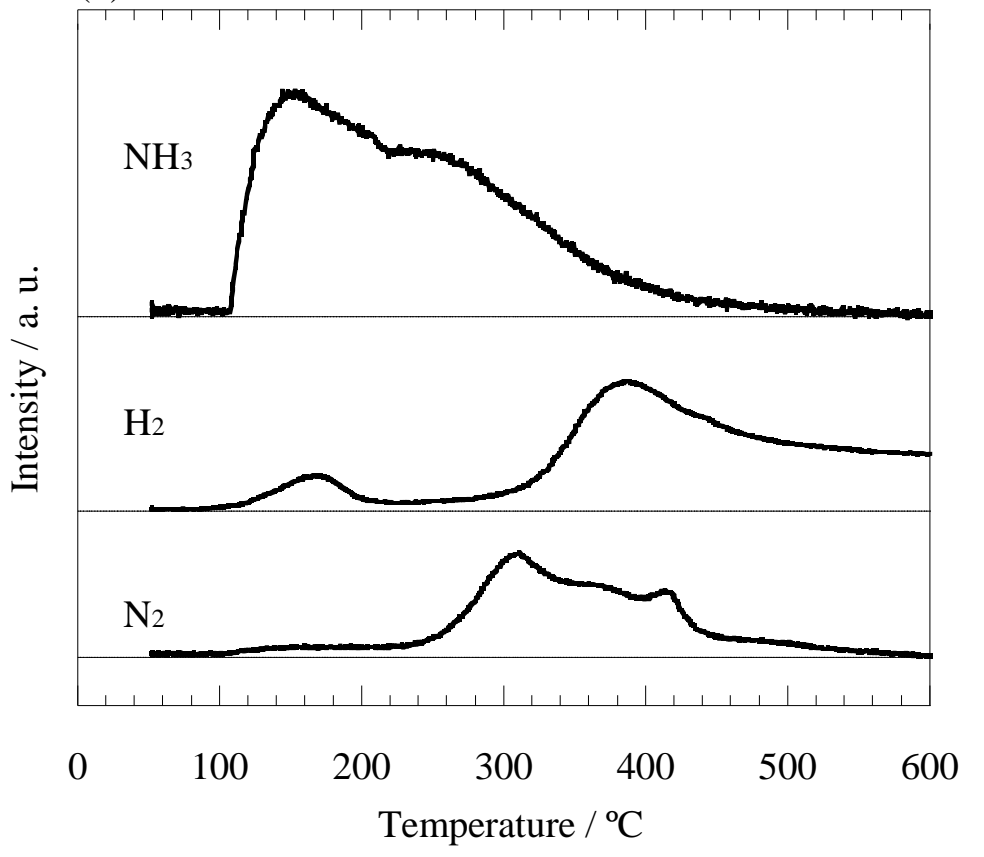

Fig. 5. K. Okura et al. 


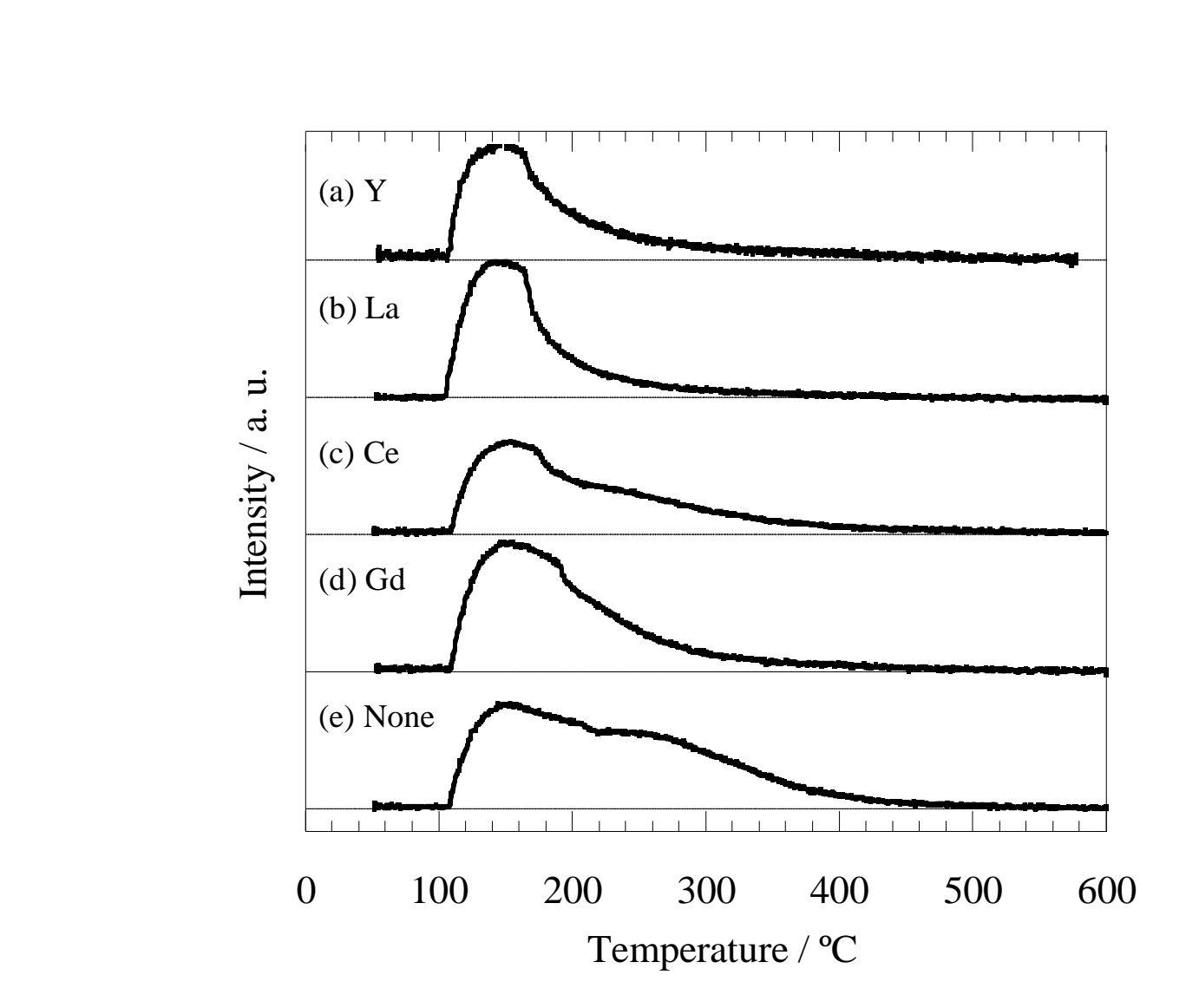

Fig. 6. K. Okura et al.

Fig. 6. K. Okura et al.

Figure 6

(1)

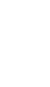

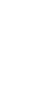
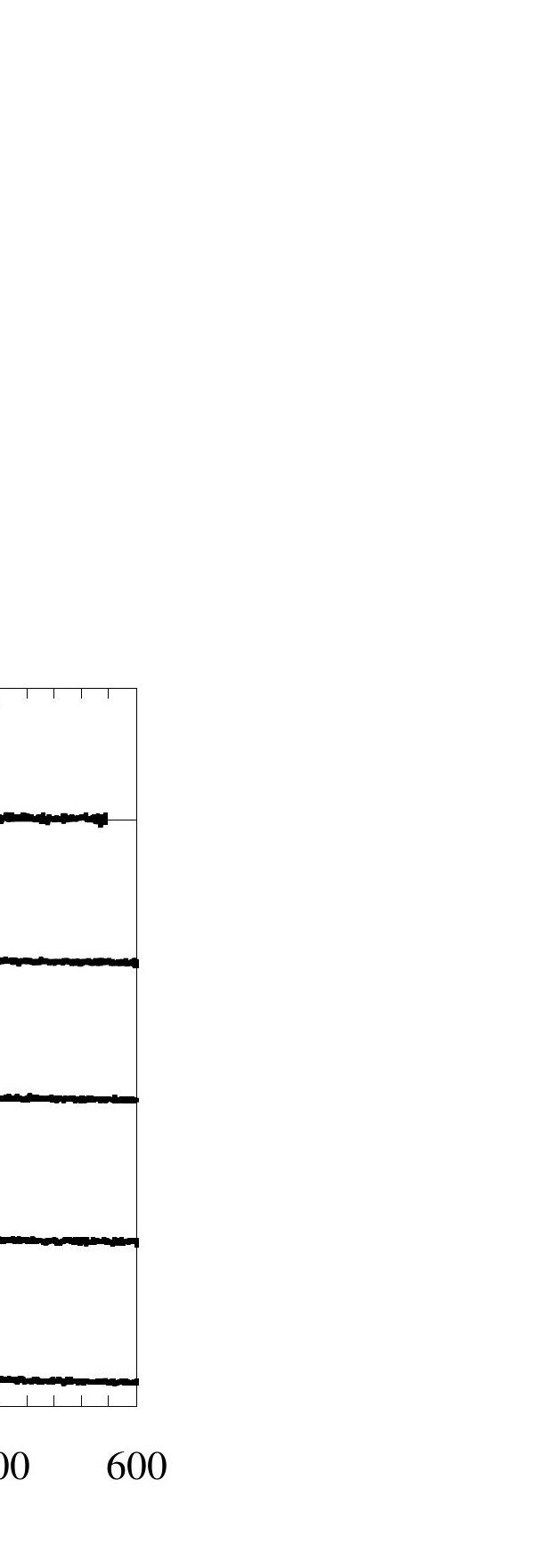

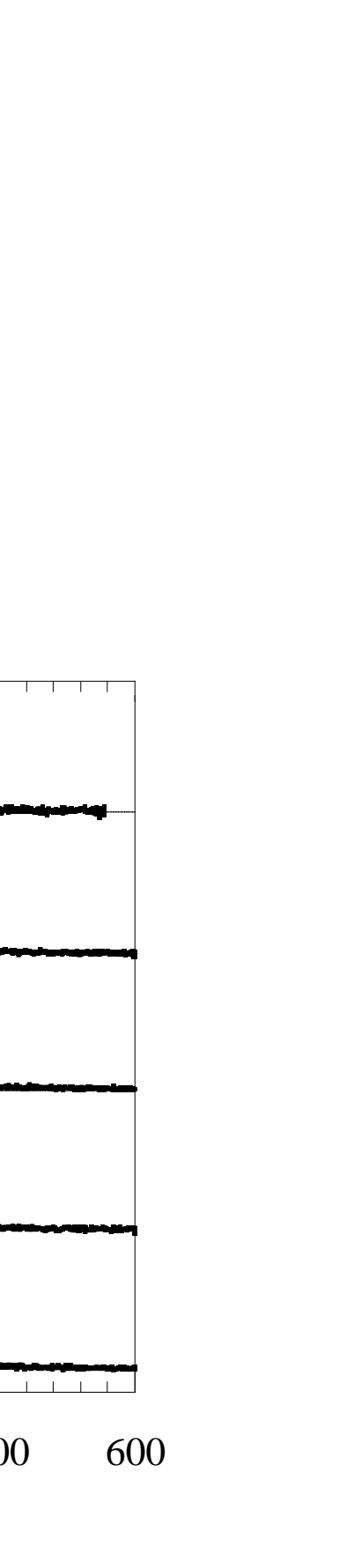

(a)

(1)
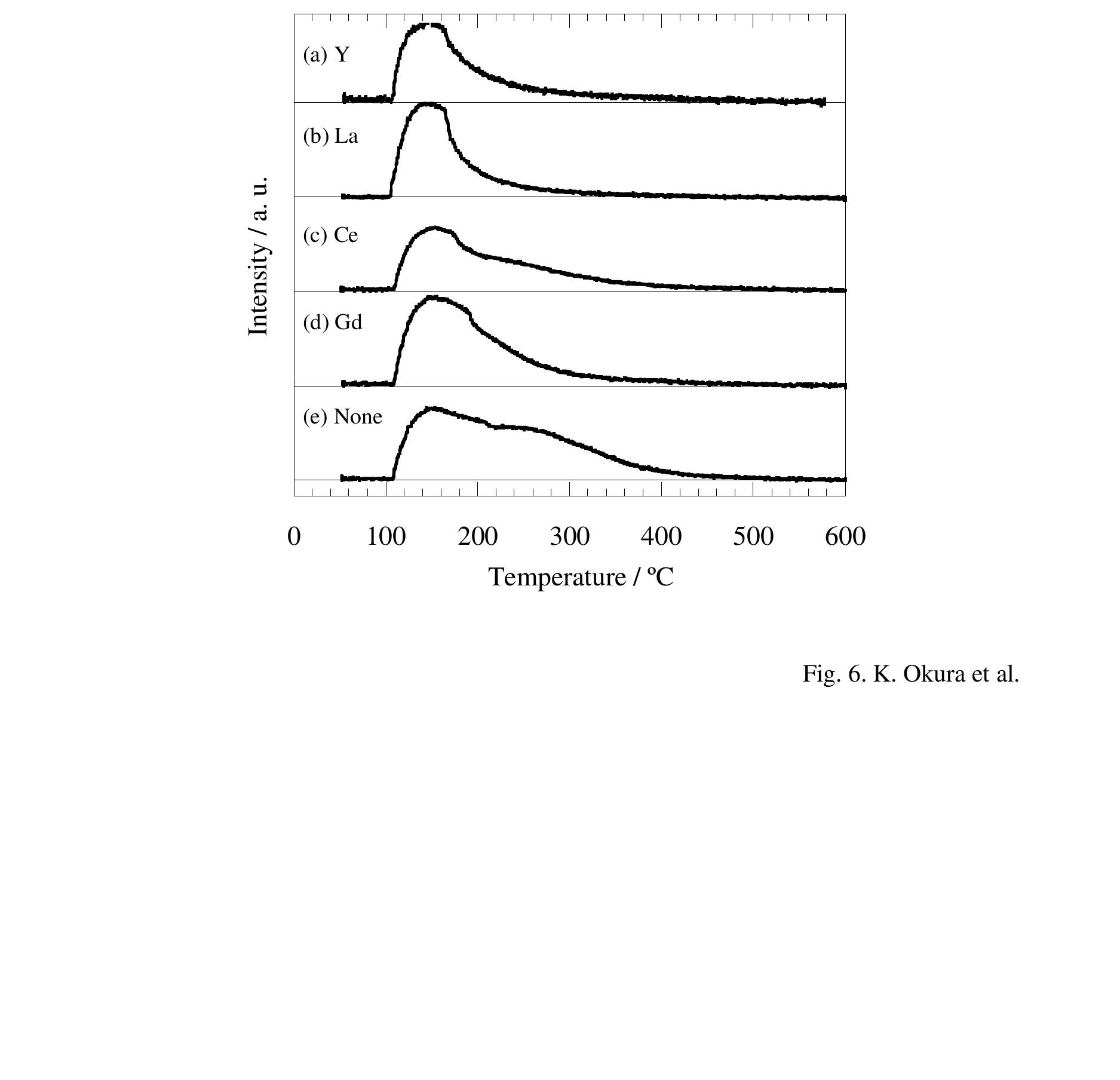


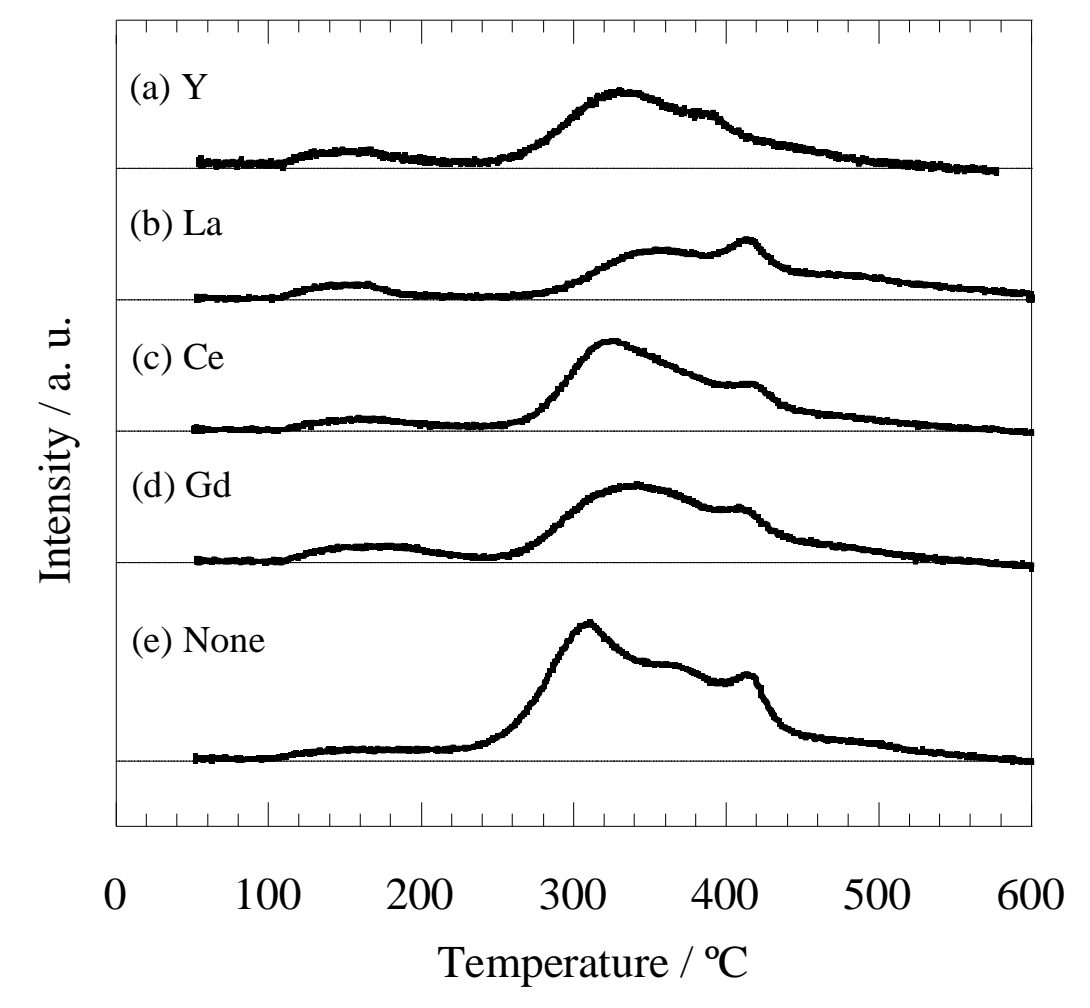

Fig. 7. K. Okura et al. 


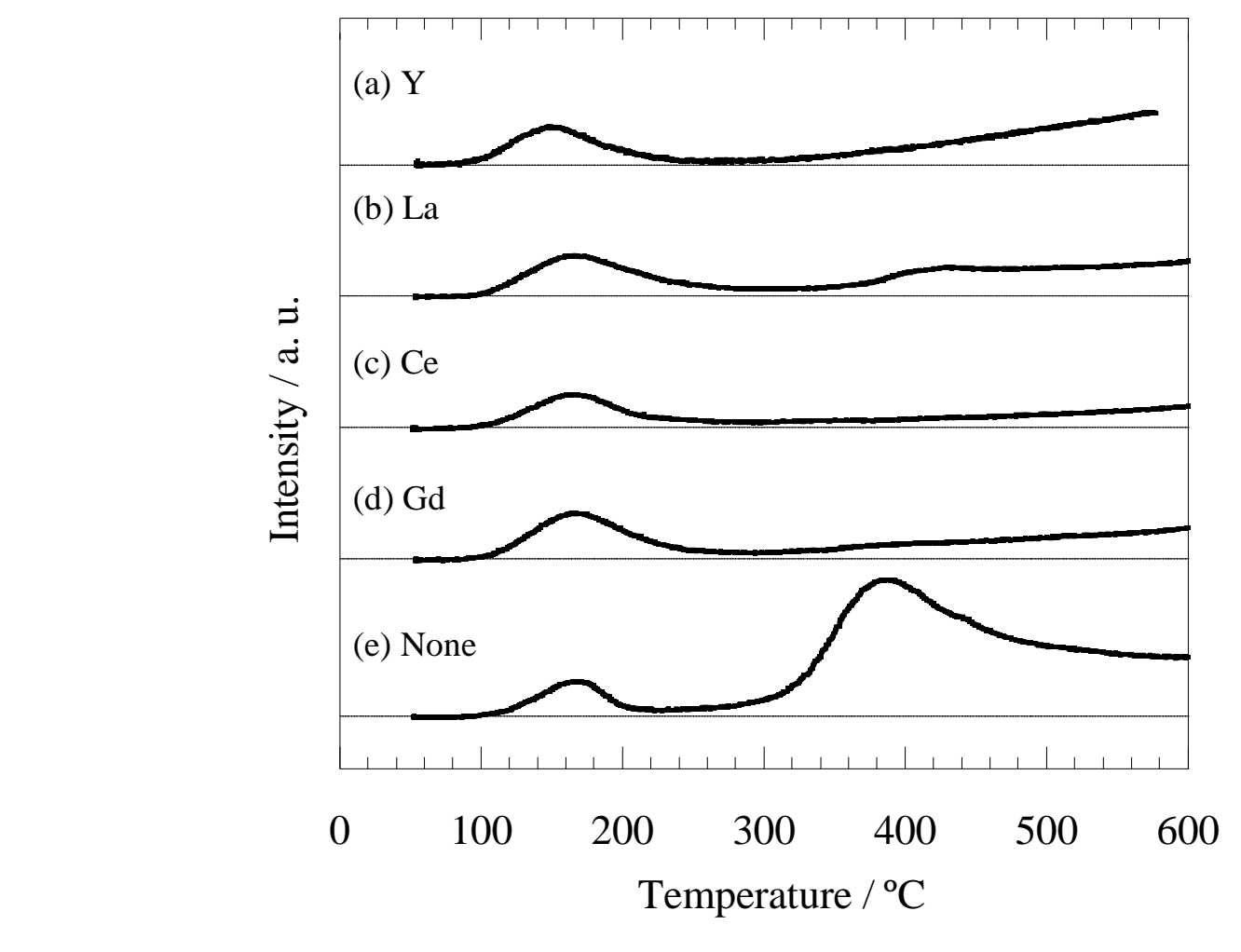

Fig. 8. K. Okura et al.

Fig. 8. K. Okura et a.

\section{8}

(1)
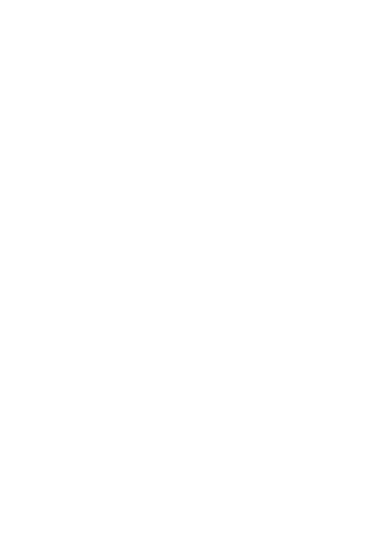
Okura et al.
(

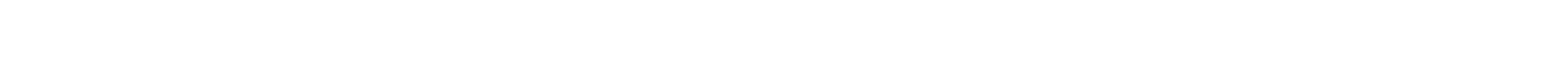




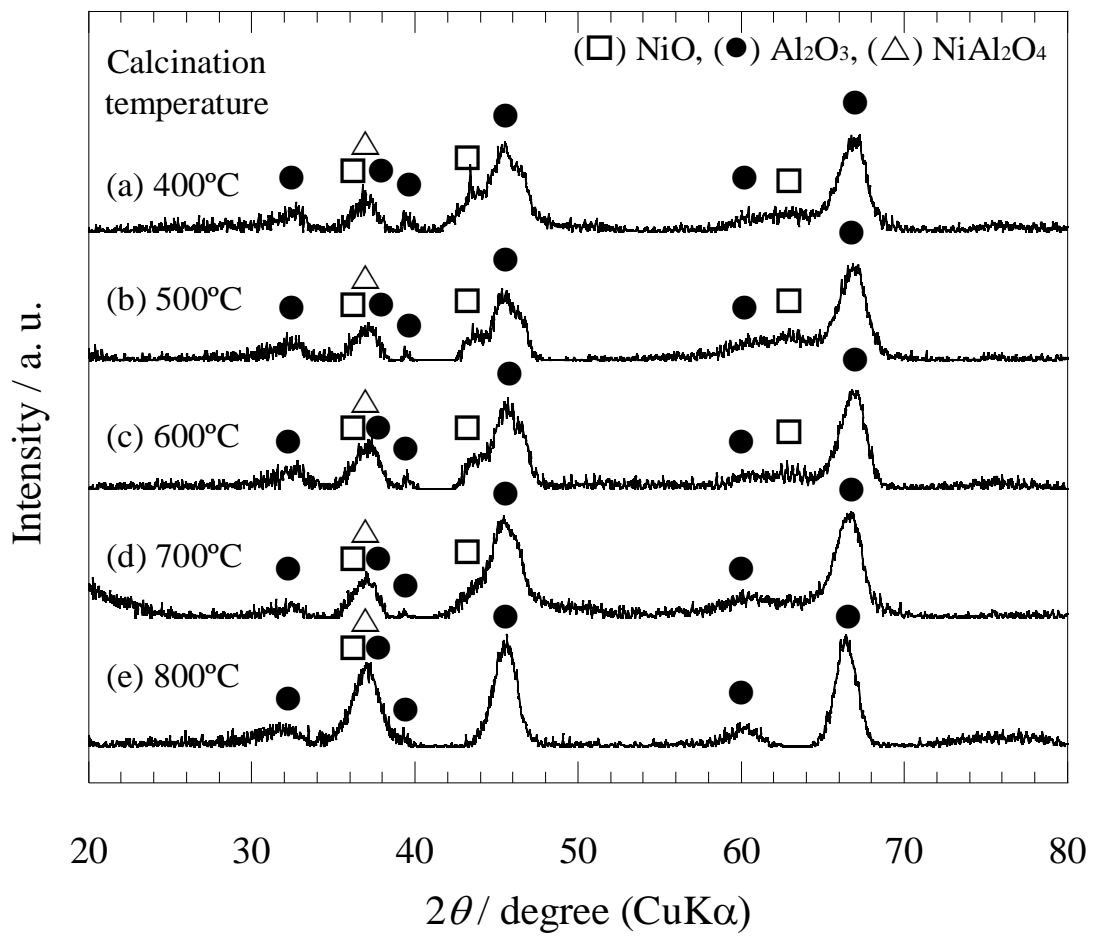

Fig. 9. K. Okura et al. 


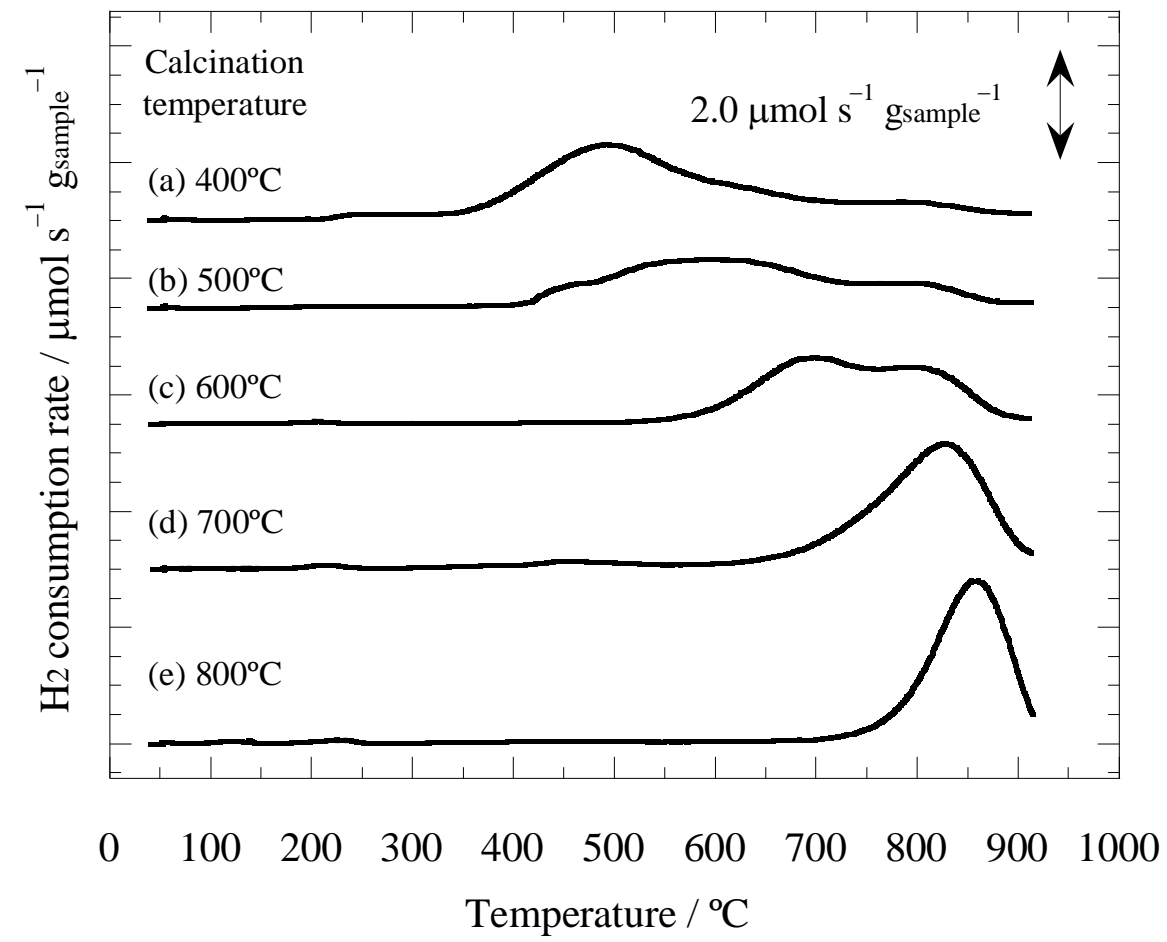

Fig. 10. K. Okura et al. 


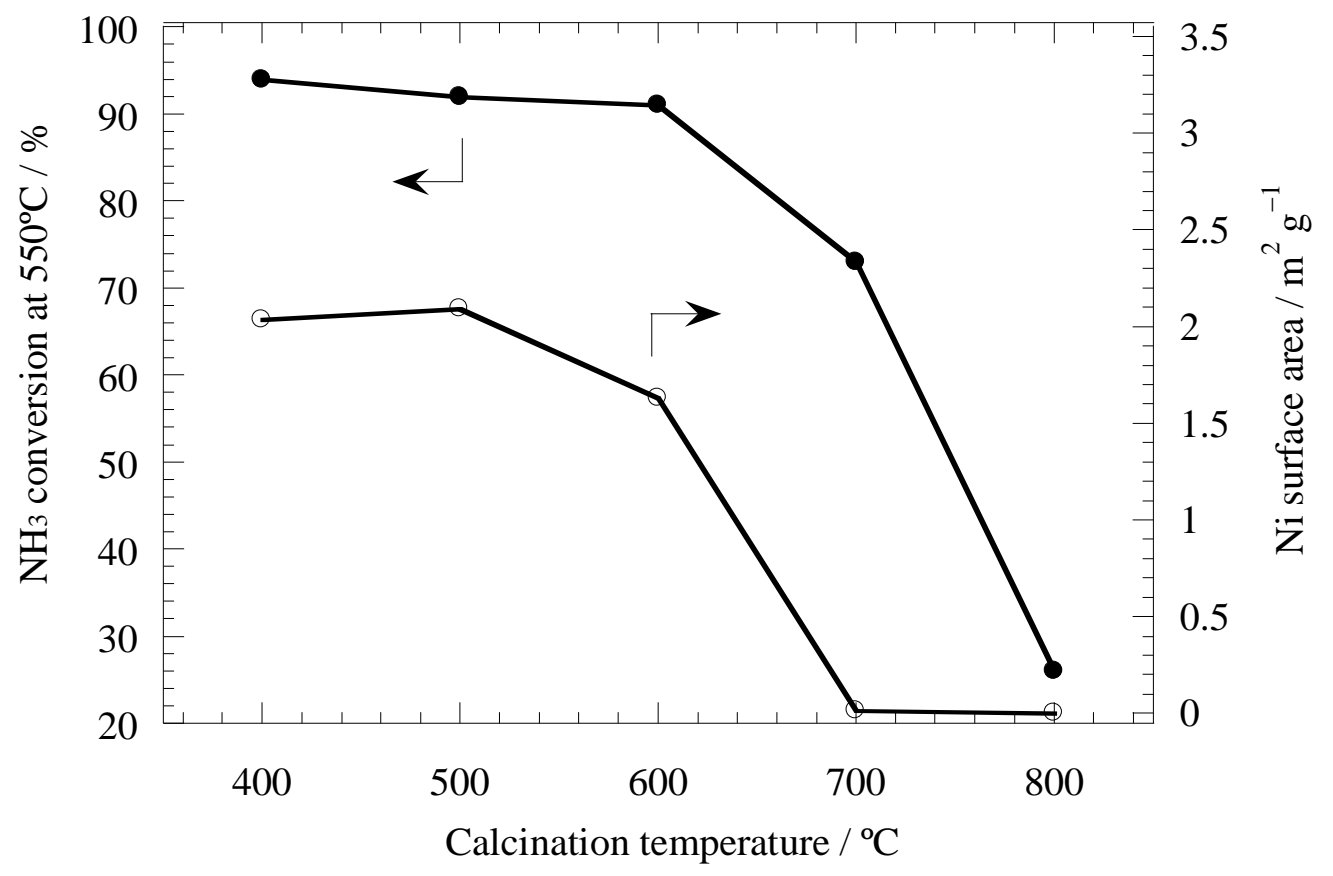

Fig. 11. K. Okura et al. 


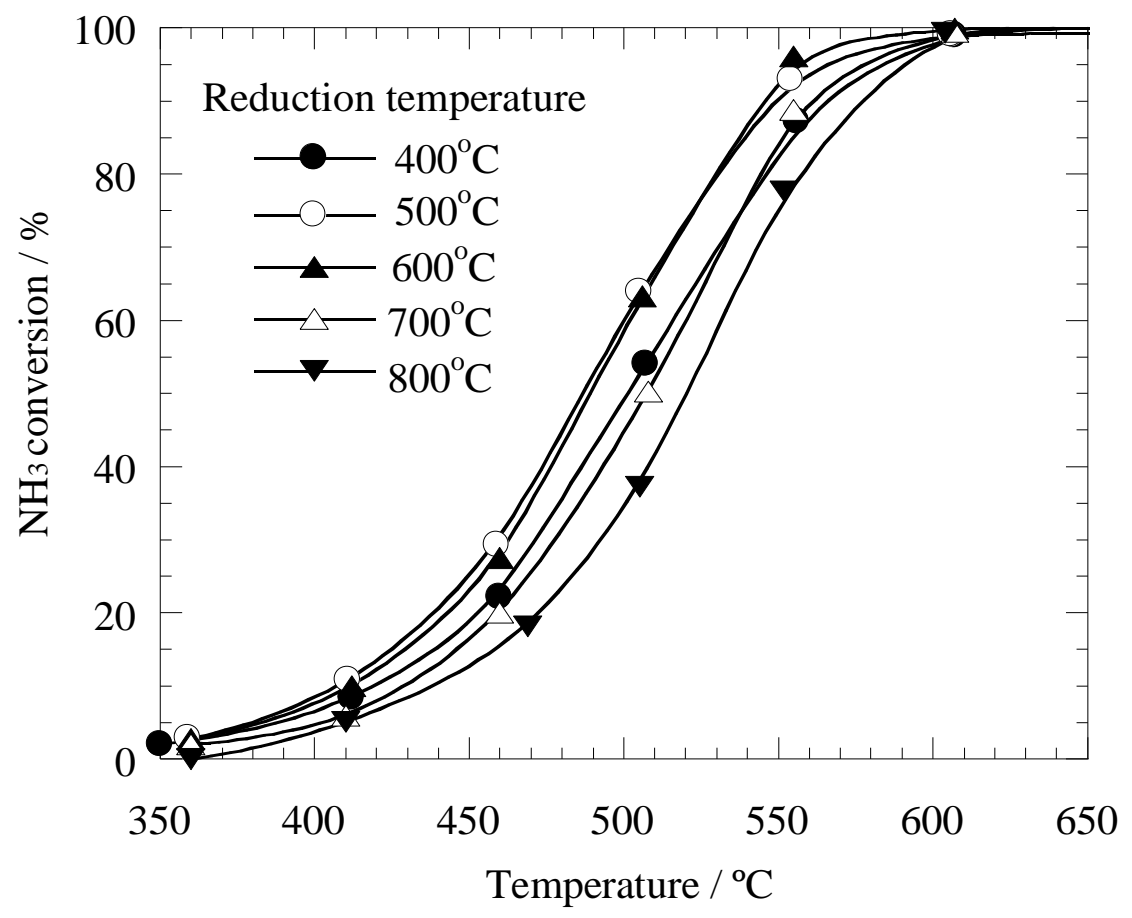

Fig. 12. K. Okura et al. 


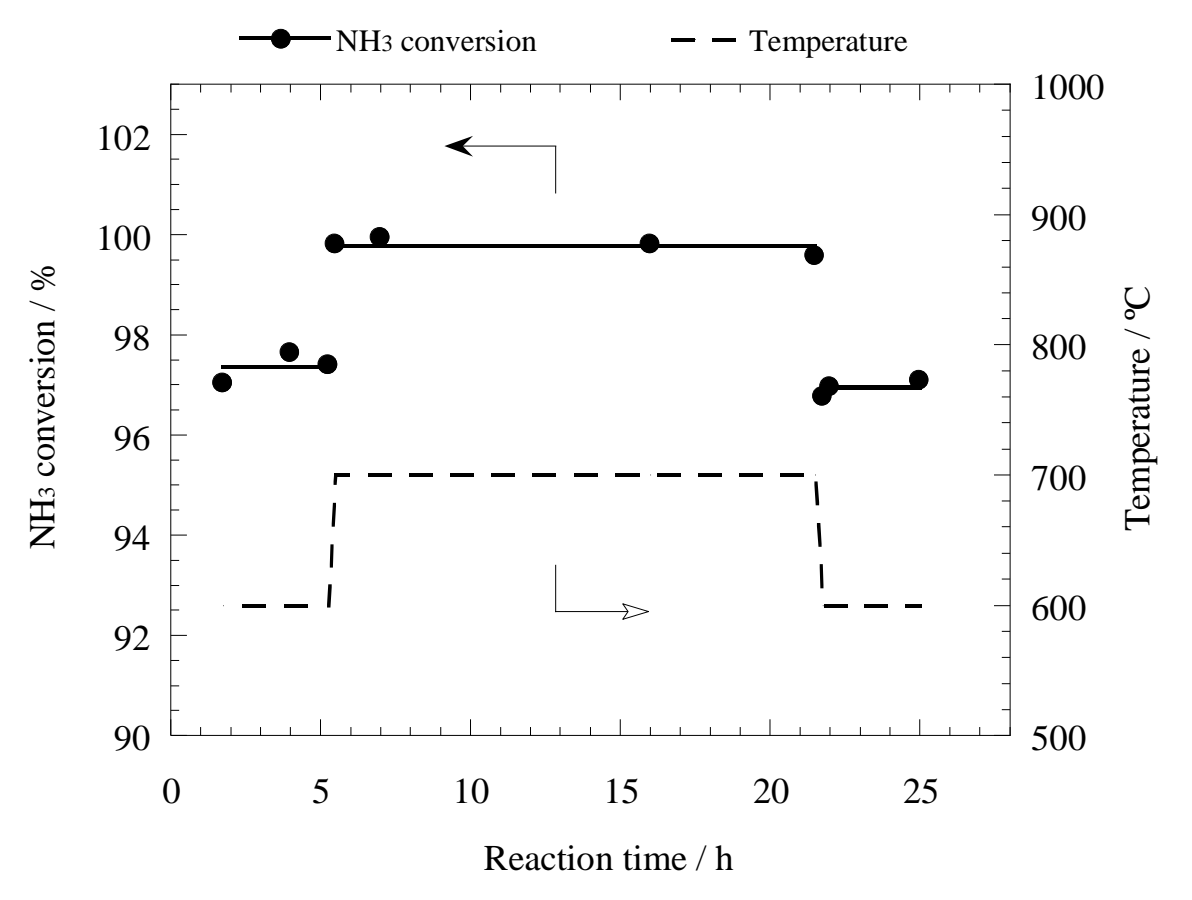

Fig. 13. K. Okura et al. 


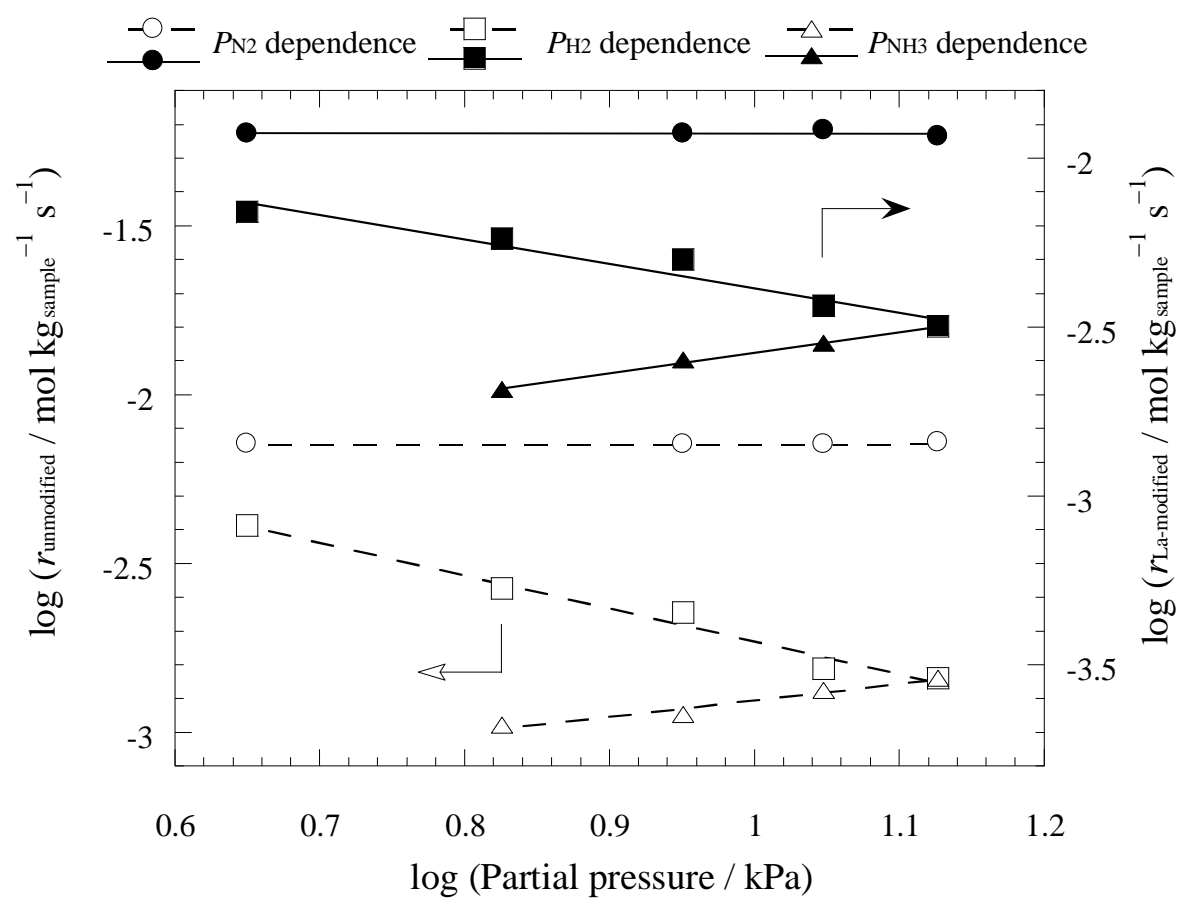

Fig. 14. K. Okura et al. 


\section{Graphical abstract}
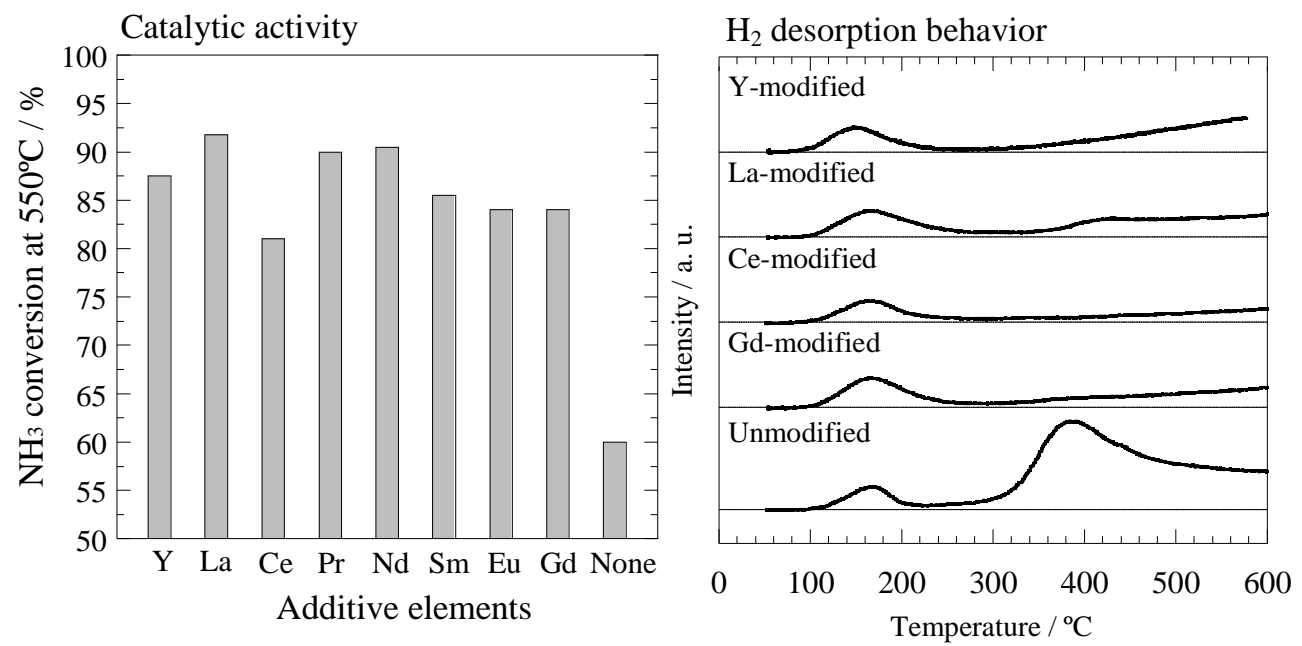